\title{
Sensitivity of nitrate aerosols to ammonia emissions and to nitrate chemistry: implications for present and future nitrate optical depth
}

\author{
F. Paulot ${ }^{1,2}$, P. Ginoux ${ }^{1}$, W. F. Cooke ${ }^{1}$, L. J. Donner ${ }^{1}$, S. Fan ${ }^{1}$, M.-Y. Lin ${ }^{1,2}$, J. Mao ${ }^{1,2}$, V. Naik ${ }^{3}$, and L. W. Horowitz ${ }^{1}$ \\ ${ }^{1}$ Geophysical Fluid Dynamics Laboratory, National Oceanic and Atmospheric Administration, Princeton, New Jersey, USA \\ ${ }^{2}$ Program in Atmospheric and Oceanic Sciences, Princeton University, New Jersey, USA \\ ${ }^{3}$ UCAR, National Oceanic and Atmospheric Administration, Princeton, New Jersey, USA
}

Correspondence to: F. Paulot (fabien.paulot@noaa.gov)

Received: 12 August 2015 - Published in Atmos. Chem. Phys. Discuss.: 22 September 2015

Revised: 15 January 2016 - Accepted: 20 January 2016 - Published: 9 February 2016

\begin{abstract}
We update and evaluate the treatment of nitrate aerosols in the Geophysical Fluid Dynamics Laboratory (GFDL) atmospheric model (AM3). Accounting for the radiative effects of nitrate aerosols generally improves the simulated aerosol optical depth, although nitrate concentrations at the surface are biased high. This bias can be reduced by increasing the deposition of nitrate to account for the nearsurface volatilization of ammonium nitrate or by neglecting the heterogeneous production of nitric acid to account for the inhibition of $\mathrm{N}_{2} \mathrm{O}_{5}$ reactive uptake at high nitrate concentrations. Globally, uncertainties in these processes can impact the simulated nitrate optical depth by up to $25 \%$, much more than the impact of uncertainties in the seasonality of ammonia emissions $(6 \%)$ or in the uptake of nitric acid on dust (13\%). Our best estimate for fine nitrate optical depth at $550 \mathrm{~nm}$ in 2010 is $0.006(0.005-0.008)$. In wintertime, nitrate aerosols are simulated to account for over $30 \%$ of the aerosol optical depth over western Europe and North America. Simulated nitrate optical depth increases by less than $30 \%(0.0061-0.010)$ in response to projected changes in anthropogenic emissions from 2010 to 2050 (e.g., $-40 \%$ for $\mathrm{SO}_{2}$ and $+38 \%$ for ammonia). This increase is primarily driven by greater concentrations of nitrate in the free troposphere, while surface nitrate concentrations decrease in the midlatitudes following lower concentrations of nitric acid. With the projected increase of ammonia emissions, we show that better constraints on the vertical distribution of ammonia (e.g., convective transport and biomass burning injection) and on the sources and sinks of nitric acid (e.g., heterogeneous reaction on dust) are needed to improve estimates of future nitrate optical depth.
\end{abstract}

\section{Introduction}

Ammonium nitrate $\left(\mathrm{NH}_{4} \mathrm{NO}_{3}\right)$ aerosols are produced by the reaction of nitric acid $\left(\mathrm{HNO}_{3}\right)$, a photochemical product of $\mathrm{NO}$ oxidation, and ammonia $\left(\mathrm{NH}_{3}\right)$. Emissions of $\mathrm{NH}_{3}$ and $\mathrm{NO}$ are primarily from anthropogenic origin: fossil fuel combustion for $\mathrm{NO}$ and agriculture for $\mathrm{NH}_{3}$ (i.e., Bouwman et al., 1997; Paulot et al., 2014). The formation of $\mathrm{NH}_{4} \mathrm{NO}_{3}$ is favored by cold temperatures and high relative humidity (Stelson and Seinfeld, 1982). $\mathrm{NH}_{4} \mathrm{NO}_{3}$ production competes with that of ammonium sulfate, which is generally more thermodynamically stable (Pinder et al., 2008), and that of coarsemode nitrate via heterogeneous uptake of $\mathrm{HNO}_{3}$ on dust and sea salt (i.e., Zhuang et al., 1999; Jacobson, 1999; Jordan et al., 2003).

$\mathrm{NH}_{4} \mathrm{NO}_{3}$ is an important component of surface particulate matter in the USA (i.e., Malm et al., 2004; Hand et al., 2012; Kim et al., 2014), Europe (i.e., Schaap et al., 2004), and Asia (i.e., Pathak et al., 2009; Ying et al., 2014), especially in winter. $\mathrm{As} \mathrm{NH}_{4} \mathrm{NO}_{3}$ rapidly volatilizes away from sources of $\mathrm{NO}$ and $\mathrm{NH}_{3}$ and with warmer temperature, it is only predicted to make an important contribution to aerosol optical depth (AOD) over polluted regions (Park et al., 2014), with global annual estimates of nitrate optical depth ranging from 0.0023 to 0.025 (Bellouin et al., 2011; Shindell et al., 2013; Myhre et al., 2013; Hauglustaine et al., 2014). However, recent modeling studies have shown that $\mathrm{NH}_{4} \mathrm{NO}_{3}$ may become the largest contributor to anthropogenic AOD by the end of the twenty-first century (Hauglustaine et al., 2014), following the projected increase of $\mathrm{NH}_{3}$ emissions and decrease of $\mathrm{SO}_{2}$ emissions. Such an increase of $\mathrm{NH}_{4} \mathrm{NO}_{3}$ 
would offset some of the decline in anthropogenic aerosol radiative forcing over the twenty-first century (West et al., 1998; Adams et al., 2001; Liao et al., 2006; Bellouin et al., 2011; Henze et al., 2012; Shindell et al., 2013; Hauglustaine et al., 2014).

In this study, we aim to characterize the mechanisms controlling the response of $\mathrm{NO}_{3}^{-}$optical depth to changes in anthropogenic emissions from 2010 to 2050 . We focus in particular on how this response is modulated by the temporal and spatial variations in $\mathrm{NH}_{3}$ emissions, the heterogeneous chemistry of $\mathrm{HNO}_{3}$, and the surface removal of nitrate aerosols. In Sect. 2, we first describe a new configuration $(\mathrm{AM} 3 \mathrm{~N})$ of the global chemistry-climate atmospheric model (AM3) from the Geophysical Fluid Dynamics Laboratory (GFDL), with revised treatments of sulfate and nitrate chemistry and aerosol deposition. We emphasize significant differences in the simulated budgets of $\mathrm{SO}_{4}^{2-}, \mathrm{NO}_{3}^{-}$, and $\mathrm{NH}_{x} \equiv \mathrm{NH}_{3}+\mathrm{NH}_{4}^{+}$between AM3N and the version of AM3 used for the Coupled Model Intercomparison Project (CMIP) 5. In Sect. 3, we evaluate the simulated distribution of AOD, as well as $\mathrm{SO}_{4}^{2-}, \mathrm{NO}_{3}^{-}$, and $\mathrm{NH}_{3}$ concentrations at the surface and in precipitated water. In particular, we evaluate AM3 and AM3N against the extensive set of aerosol composition and optical properties routinely measured at Bondville $\left(40.1^{\circ} \mathrm{N}\right.$, $88.4^{\circ} \mathrm{W}$ ). In Sect. 4 , we examine the response of $\mathrm{NO}_{3}^{-}$optical depth to projected changes in anthropogenic emissions in 2050 and its sensitivity to different treatments of removal and chemistry.

\section{Method}

\subsection{Model description}

We use the GFDL-AM3 chemistry-climate model to simulate gas and aerosol chemistry. In its standard form, AM3 uses a finite volume dynamical core on a cubed sphere grid with $200 \mathrm{~km}$ (c48) horizontal resolution and 48 hybrid sigma pressure vertical layers (Donner et al., 2011). AM3 simulations were conducted for the Atmospheric Chemistry and Climate Model Intercomparison Project (ACCMIP) (Naik et al., 2013b) and as the atmospheric component of the GFDL coupled climate model CM3 for CMIP5 in support of the IPCC AR5.

The chemistry of AM3 has been described by Naik et al. (2013a) with updates to the gas-phase and heterogeneous chemistry (Mao et al., 2013b, c). Briefly, AM3 includes $\mathrm{SO}_{4}^{2-}$ formation from gas-phase oxidation and the in-cloud reaction of $\mathrm{SO}_{2}$ with $\mathrm{O}_{3}$ and $\mathrm{H}_{2} \mathrm{O}_{2}$ (Tie et al., 2005). Incloud production of $\mathrm{SO}_{4}^{2-}$ is sensitive to cloud $\mathrm{pH}$, which is calculated as a function of the concentration of $\mathrm{SO}_{4}^{2-}$ (assumed to be entirely in-cloud water), $\mathrm{NH}_{3}, \mathrm{SO}_{2}, \mathrm{HNO}_{3}$, and $\mathrm{CO}_{2} . \mathrm{NH}_{4} \mathrm{NO}_{3}$ formation is calculated following Stelson and Seinfeld (1982), but is assumed irreversible. Dry deposition and wet scavenging by large-scale and convective precipita- tion are described by Fang et al. (2011); Donner et al. (2011); Naik et al. (2013a).

Aerosol optical properties (i.e., extinction efficiency, single-scattering albedo, and asymmetry parameter) are described by Donner et al. (2011) and Strong et al. (2015). Sulfate is assumed to be fully neutralized by ammonium. Its size distribution is taken as log-normal following Haywood and Ramaswamy (1998) with hygroscopic growth based on pure ammonium sulfate (Tang and Munkelwitz, 1994) and capped at $95 \%$ relative humidity. Aerosol activation into cloud droplets follows the parameterization of Ming et al. (2006). For radiative calculations, aerosols are assumed to be externally mixed except for sulfate and hydrophilic black carbon, which are assumed internally mixed (Donner et al., 2011). Nitrate is not considered for radiative calculations in AM3.

A new configuration of AM3 is introduced (referred to as AM3N hereafter) with the following changes aimed at improving the simulation of nitrate aerosols (see Sect. 3).

Aerosol chemistry - we use ISORROPIA to simulate the sulfate-nitrate-ammonia thermodynamic equilibrium (Fountoukis and Nenes, 2007). Equilibrium between gas and aerosol is assumed to be reached at each model time step (30 min), which is generally justified for $\mathrm{PM}_{2.5}$ (Meng and Seinfeld, 1996). In-cloud oxidation of $\mathrm{SO}_{2}$ is restricted to liquid clouds and we revise the calculation of cloud $\mathrm{pH}$ to account for the partitioning of $\mathrm{HNO}_{3} / \mathrm{NO}_{3}^{-}$and $\mathrm{NH}_{3} / \mathrm{NH}_{4}^{+}$ between the gas phase and cloud water.

Heterogeneous chemistry - we include the heterogeneous uptake of $\mathrm{HNO}_{3}, \mathrm{NO}_{3}^{-}, \mathrm{N}_{2} \mathrm{O}_{5}, \mathrm{SO}_{2}$, and $\mathrm{H}_{2} \mathrm{SO}_{4}$ on dust particles (Table $\mathrm{S} 1$ in the Supplement). The uptake of $\mathrm{HNO}_{3}$, $\mathrm{NO}_{3}^{-}$, and $\mathrm{N}_{2} \mathrm{O}_{5}$ is assumed to be limited by alkalinity (Song and Carmichael, 2001). Following Fairlie et al. (2010), dust alkalinity is comprised of calcium and magnesium carbonates, with calcium and magnesium constituting 3 and $0.6 \%$ (by mass) of coarse dust emissions (radius $>1 \mu \mathrm{m}$ ), respectively. Observations suggest alkalinity is primarily found in the coarse mode (Claquin et al., 1999); we assume that fine dust carries half as much alkalinity per kilogram as coarse dust. We also reduce the reaction probabilities $(\gamma)$ of $\mathrm{N}_{2} \mathrm{O}_{5}$, $\mathrm{NO}_{2}$, and $\mathrm{NO}_{3}$ on aerosols relative to AM3 (Mao et al., 2013b) (see Table S1 in the Supplement and Sect. 2.3.2). The implications of these changes for the budget of $\mathrm{HNO}_{3}$ and aerosol $\mathrm{NO}_{3}^{-}$are described in Sect. 2.4.

Nitrate optical depth - the optical properties and the mixing with black carbon of ammonium nitrate are assumed to be identical to those of ammonium sulfate. This approximation introduces an error in mass extinction at $550 \mathrm{~nm}$ of less than $20 \%$ for relative humidity (RH) $<90 \%$ and by less than $10 \%$ between 90 and $95 \%$ (Fig. S1 in the Supplement). The optical depth of $\mathrm{NO}_{3}^{-}$associated with dust is expected to be small relative to fine-mode $\mathrm{NO}_{3}^{-}$(e.g., Hauglustaine et al., 2014) and it is not considered here.

Dry deposition - similar to AM3, the dry deposition fluxes of gases and fine aerosols are calculated based on a monthly 
climatology of deposition velocities. We update this climatology to account for recent observations of rapid deposition of $\mathrm{H}_{2} \mathrm{O}_{2}$ and some oxygenated volatile organic compounds, using the deposition velocities calculated in the GEOS-Chem chemical transport model as described by Nguyen et al. (2015).

Wet deposition - in AM3, aerosol removal by snow is treated like that by rain. In AM3N, water-soluble aerosols are not removed by snow, when the snow is formed via the Wegener-Bergeron-Findeisen mechanism (referred to as Bergeron mechanism hereafter), i.e., when water evaporates from liquid cloud droplets and condenses onto growing ice crystals. This treatment is consistent with observations (Henning et al., 2004) and similar to that used in other global models (Liu et al., 2011; Wang et al., 2011; Fan et al., 2012). Scavenging by snow formed via riming and homogeneous freezing is treated like that by rain. Gases are not scavenged by snow except $\mathrm{HNO}_{3}$ (Neu and Prather, 2012). Convective plumes are discretized on a vertical grid that has finer vertical resolution than AM3 (Donner, 1993). The improved discretization of the convective plume has little impact on precipitation at the surface but increases the convective wet removal of tracers as we will show in Sect. 3 .

\subsection{Emissions}

We use anthropogenic emissions from the Hemispheric Transport of Air Pollution v2 (HTAP_v2) task force regridded to $0.5^{\circ} \times 0.5^{\circ}$ for years 2008 and 2010 (JanssensMaenhout et al., 2015). HTAP_v2 aircraft emissions are distributed vertically following Lamarque et al. (2010). Daily biomass burning emissions are based on the NCAR Fire INventory (FINNv1, Wiedinmyer et al., 2011) and emitted in the model surface layer. Average dust emissions are parameterized following Ginoux et al. (2001), as

$F_{p}=C S s_{p} u_{10 \mathrm{~m}}^{2}\left(u_{10 \mathrm{~m}}-u_{\mathrm{t}}\right)$ if $u_{10 \mathrm{~m}}>u_{\mathrm{t}}$,

where $C$ is a dimensional factor $\left(\mu \mathrm{g} \mathrm{s}^{2} \mathrm{~m}^{-5}\right), S$ is the source function based on topography, $u_{10 \mathrm{~m}}$ is the horizontal wind at $10 \mathrm{~m}\left(\mathrm{~m} \mathrm{~s}^{-1}\right), u_{\mathrm{t}}$ is the threshold velocity $\left(\mathrm{m} \mathrm{s}^{-1}\right)$, and $s_{p}$ is the fraction of total dust emitted in the size class $p$ as defined by $\mathrm{Li}$ et al. (2008). Over the 2008-2010 period, dust emission is $1640 \mathrm{Tg} \mathrm{a}^{-1}$. This includes $1230 \mathrm{Tg} \mathrm{a}^{-1}$ from natural sources ( $S$ from Ginoux et al. (2001), $C=$ $\left.0.125 \mu \mathrm{g} \mathrm{s}^{2} \mathrm{~m}^{-5}, u_{\mathrm{t}}=1 \mathrm{~m} \mathrm{~s}^{-1}\right)$, similar to the AEROCOM multi-model mean (Huneeus et al., 2011), and $410 \mathrm{Tg} \mathrm{a}^{-1}$ from anthropogenic sources (primarily over cropland and pasture from Ginoux et al. (2012b) with updated MODIS collection $6, C=0.219 \mu \mathrm{g} \mathrm{s}^{2} \mathrm{~m}^{-5}, u_{\mathrm{t}}=3 \mathrm{~m} \mathrm{~s}^{-1}$ ). Isoprene emissions are calculated using the Model of Emissions of Gases and Aerosols from Nature (MEGAN, Guenther et al., 2006; Rasmussen et al., 2012). NO emissions from lightning are calculated as a function of subgrid convection (Horowitz et al., 2003). Differences in the treatment of convection in AM3N result in greater $\mathrm{NO}$ emissions from lightning in
AM3N (5.6 $\left.\mathrm{Tg} \mathrm{Na}^{-1}\right)$ compared to AM3 $\left(5.2 \mathrm{Tg} \mathrm{Na}^{-1}\right)$, with both estimates within the range of emissions inferred from observations (Martin et al., 2007; Murray et al., 2012). Other natural emissions, including soil $\mathrm{NO}_{x}$ and soil and ocean $\mathrm{NH}_{3}$ emissions, are described by Donner et al. (2011) and Naik et al. (2013a). Global total emissions of $\mathrm{SO}_{2}, \mathrm{NH}_{3}$, and $\mathrm{NO}_{x}$ are listed in Table 1.

\subsection{Sensitivity simulations}

Considering the large uncertainty in the simulated nitrate optical depth and surface concentrations, we design a set of sensitivity simulations based on AM3N to characterize the sensitivity of nitrate and sulfate to key uncertainties in chemistry and in $\mathrm{NH}_{3}$ emissions (Table 2). All simulations are run from 2007 to 2010, using 2007 to spin-up the model. To facilitate the comparison with observations and limit meteorological variability across model configurations, the model horizontal wind is relaxed to 6 hourly values from the National Centers for Environmental Predictions reanalysis (Kalnay et al., 1996) as described in Lin et al. (2012).

\subsection{1 $\mathrm{NH}_{3}$ emissions}

Present-day - the largest source of $\mathrm{NH}_{3}$ to the atmosphere is agriculture. Unlike anthropogenic emissions of other compounds, which are dominated by fossil fuel emissions, $\mathrm{NH}_{3}$ emissions exhibit large seasonal variations, which reflect the seasonality of agricultural practices (e.g., fertilizer application) as well as the decrease of $\mathrm{NH}_{3}$ solubility with temperature (Misselbrook et al., 2004; Pinder et al., 2006; Paulot et al., 2014). The HTAP_v2 inventory includes monthly variations in anthropogenic $\mathrm{NH}_{3}$ emissions over North America, Europe, and parts of Asia, including Japan and China, but excluding India. Anthropogenic emissions of $\mathrm{NH}_{3}$ previously used in AM3 simulations for ACCMIP and CMIP5 are constant throughout the year (Lamarque et al., 2010). To evaluate the impact of the seasonality of $\mathrm{NH}_{3}$ emissions on $\mathrm{NO}_{3}^{-}$, we remove all temporal variability in the anthropogenic emissions of $\mathrm{NH}_{3}$ in simulation $\mathrm{AM} 3 \mathrm{~N} \_n s$. $\mathrm{NH}_{3}$ emissions also exhibit diurnal variability (Pinder et al., 2006), which may affect the simulated concentrations of $\mathrm{NH}_{3}$ and $\mathrm{NH}_{4} \mathrm{NO}_{3}$ (Zhu et al., 2013; Van Damme et al., 2014b; Schiferl et al., 2014; Zhu et al., 2015). In AM3N_diu, we impose the $\mathrm{NH}_{3}$ diurnal cycle of the regional LOTOS (Long Term Ozone Simulation) model globally (Schaap et al., 2004). The ratio between maximum emissions (13:00-14:00 local time) and minimum emissions (03:00-06:00) is 5.7 .

2050 - anthropogenic $\mathrm{NH}_{3}$ emissions for 2050 are estimated by scaling HTAP_v2 surface anthropogenic $\mathrm{NH}_{3}$ emissions with national projections from the Representative Concentration Pathway 8.5 (RCP8.5) from 2010 to 2050 (Fig. 1), while keeping natural and biomass burning emissions at their present-day levels. We use the RCP8.5 scenario for 2050 (van Vuuren et al., 2011) as it most closely resem- 
Table 1. Simulated budget of $\mathrm{SO}_{4}, \mathrm{NH}_{x}$, and $\mathrm{NO}_{y}$ in 2010 .

\begin{tabular}{|c|c|c|}
\hline & AM3 & AM3N \\
\hline \multicolumn{3}{|l|}{$\mathrm{SO}_{4}^{2-\mathrm{a}}$} \\
\hline Production $\left(\mathrm{Tg} \mathrm{S} \mathrm{a}^{-1}\right)$ & 37.3 & 33.1 \\
\hline $\mathrm{OH}$ & 10.4 & 7.7 \\
\hline $\mathrm{H}_{2} \mathrm{O}_{2}$ & 26.7 & 16.2 \\
\hline $\mathrm{O}_{3}$ & 0.1 & 4.5 \\
\hline dust & 0.0 & 1.9 \\
\hline $\operatorname{Loss}\left(\mathrm{Tg} \mathrm{S} \mathrm{a}^{-1}\right)$ & 37.4 & 33.3 \\
\hline Dry deposition & 4.7 & 4.6 \\
\hline $\mathrm{SO}_{4}^{2-}$ & 4.7 & 3.8 \\
\hline $\mathrm{SO}_{4}^{2-}$ on dust & 0.0 & 0.8 \\
\hline Wet deposition & 32.7 & 28.7 \\
\hline $\mathrm{SO}_{4}^{2-}$ & 32.7 & 27.5 \\
\hline $\mathrm{SO}_{4}^{2-}$ on dust & 0.0 & 1.1 \\
\hline Lifetime (days) & 4.9 & 3.8 \\
\hline \multicolumn{3}{|l|}{$\mathrm{NH}_{x}$} \\
\hline $\mathrm{NH}_{3}$ emission $\left(\mathrm{Tg} \mathrm{Na}^{-1}\right)^{\mathrm{b}}$ & 54.5 & 54.5 \\
\hline Loss $\left(\mathrm{Tg} \mathrm{Na}^{-1}\right)$ & 54.8 & 55.0 \\
\hline Dry deposition & 14.4 & 23.5 \\
\hline $\mathrm{NH}_{4}^{+}$ & 14.3 & 3.6 \\
\hline $\mathrm{NH}_{3}^{4}$ & 0.1 & 19.9 \\
\hline Wet deposition & 40.4 & 30.7 \\
\hline $\mathrm{NH}_{4}^{+}$ & 39.4 & 20.7 \\
\hline $\mathrm{NH}_{3}^{4}$ & 1.0 & 10.1 \\
\hline Gas oxidation & 0.0 & 0.8 \\
\hline Lifetime (days) & 5.5 & 2.5 \\
\hline \multicolumn{3}{|l|}{$\mathrm{NO}_{y}$} \\
\hline NO emission $\left(\mathrm{Tg} \mathrm{Na}^{-1}\right)$ & 51.4 & 51.8 \\
\hline $\operatorname{Loss}\left(\mathrm{Tg} \mathrm{Na}^{-1}\right)$ & 51.3 & 51.0 \\
\hline Dry deposition & 25.4 & 23.1 \\
\hline $\mathrm{HNO}_{3}$ & 18.3 & 10.7 \\
\hline $\mathrm{NO}_{3}^{-}$on dust & 0.0 & 3.4 \\
\hline $\mathrm{NH}_{4} \mathrm{NO}_{3}$ & 0.7 & 0.8 \\
\hline Organic nitrogen & 3.9 & 4.0 \\
\hline Wet deposition & 25.6 & 27.6 \\
\hline $\mathrm{HNO}_{3}$ & 23.4 & 17.8 \\
\hline $\mathrm{NO}_{3}^{-}$on dust & 0.0 & 3.7 \\
\hline $\mathrm{NH}_{4}^{3} \mathrm{NO}_{3}$ & 0.5 & 3.5 \\
\hline Organic nitrogen & 1.7 & 2.6 \\
\hline Lifetime (days) & 22.7 & 13.4 \\
\hline \multicolumn{3}{|c|}{$\begin{array}{l}\text { a } \mathrm{SO}_{2} \text { emissions are } 74.0 \mathrm{Tg} \mathrm{a} \mathrm{a}^{-1} \text { including } 16.0 \mathrm{Tg} \mathrm{S} \mathrm{a}^{-1} \\
\text { from dimethyl sulfide (DMS) oxidation. } \\
\text { b including } 39.9 \mathrm{Tg} \mathrm{Na}^{-1} \text { from anthropogenic sources, } \\
3.9 \mathrm{Tg} \mathrm{Na}^{-1} \text { from biomass burning, and } 10.7 \mathrm{Tg} \mathrm{N} \mathrm{a}^{-1} \text { from } \\
\text { natural sources (primaily from the ocean). }\end{array}$} \\
\hline
\end{tabular}

bles emissions from regional inventories over the 2000-2010 period (Granier et al., 2011). However, we do not use the RCP8.5 spatial distribution of $\mathrm{NH}_{3}$ sources, as it differs notably from HTAP_v2 over many source regions such as India, the Nile delta, the Benelux, the California Central Val-

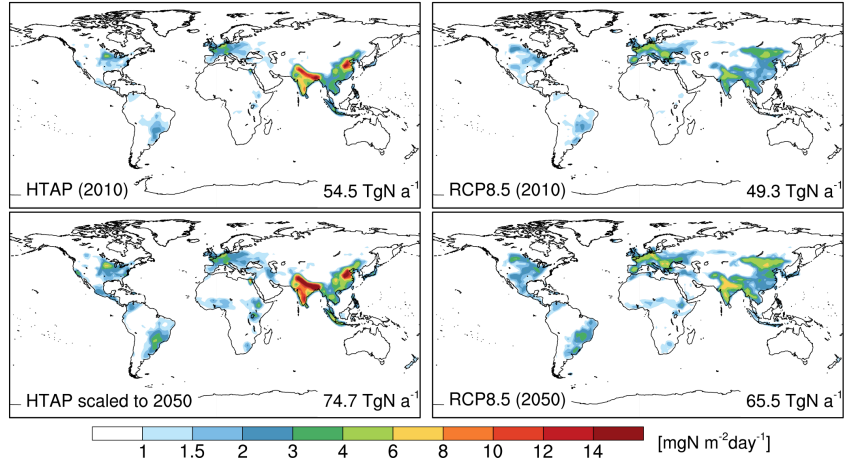

Figure 1. Average annual emissions of $\mathrm{NH}_{3}$ for 2010 (top row) and 2050 (bottom row) based on anthropogenic $\mathrm{NH}_{3}$ emissions from HTAP_v2 (left column) and from RCP8.5 (right column). Non anthropogenic emissions (including biomass burning) are the same in all scenarios. Total annual emissions are indicated inset.

ley, and the Saskatchewan (Fig. 1). These differences may reflect mapping errors for $\mathrm{RCP} 8.5 \mathrm{NH}_{3}$ emissions from agriculture as noted by Lamarque et al. (2013). Our approach results in $18 \%$ more anthropogenic emissions $\left(60 \mathrm{Tg} \mathrm{Na}^{-1}\right)$ than in RCP8.5 for 2050.

\subsubsection{Heterogeneous chemistry}

Wintertime production of $\mathrm{HNO}_{3}$ in the northern midlatitudes' boundary layer is dominated by the uptake of $\mathrm{N}_{2} \mathrm{O}_{5}$ on aerosols (e.g., Dentener and Crutzen, 1993; Tie et al., 2003; Lamsal et al., 2010). The probability for the heterogeneous conversion of $\mathrm{N}_{2} \mathrm{O}_{5}$ to $\mathrm{HNO}_{3}(\gamma)$ remains uncertain (Chang et al., 2011), with field and laboratory observations showing that it is inhibited by aerosol nitrate and organics (Brown et al., 2009; Brown and Stutz, 2012; Wagner et al., 2013; Gaston et al., 2014), but enhanced by cold temperatures (Griffiths and Anthony Cox, 2009; Wagner et al., 2013). To quantify the impact of the heterogeneous production of $\mathrm{HNO}_{3}$ on aerosol $\mathrm{NO}_{3}^{-}$, we neglect the heterogeneous production of $\mathrm{HNO}_{3}$ via $\mathrm{N}_{2} \mathrm{O}_{5}$ aerosol uptake in AM3N_nhet. We also neglect the productions of $\mathrm{HNO}_{3}$ by $\mathrm{NO}_{3}$ and $\mathrm{NO}_{2}$ reactive uptake, as they may modulate the wintertime budget of $\mathrm{NO}_{\mathrm{y}}$ in polluted region (Paulot et al., 2013). Note that previous characterizations of $\mathrm{NO}_{3}^{-}$optical depth also neglected the heterogeneous chemistry of oxidized nitrogen (e.g., Bellouin et al., 2011).

We also evaluate the impact of the heterogeneous chemistry on dust as it is not included in all models (e.g., Pye et al., 2009; Bellouin et al., 2011). In AM3N_ndust, we neglect the uptake of $\mathrm{HNO}_{3}, \mathrm{~N}_{2} \mathrm{O}_{5}, \mathrm{NO}_{3}, \mathrm{H}_{2} \mathrm{SO}_{4}$, and $\mathrm{SO}_{2}$ on dust. 
Table 2. Configurations of AM3N used in this study.

\begin{tabular}{lllll}
\hline & $\begin{array}{l}\text { Temporal variation } \\
\text { of } \mathrm{NH}_{3} \text { emissions }\end{array}$ & $\begin{array}{l}\text { Heterogeneous } \\
\text { chemistry on dust }\end{array}$ & $\begin{array}{l}\text { Heterogeneous } \\
\text { production of } \mathrm{HNO}_{3}\end{array}$ & $\begin{array}{l}\text { Dry deposition } \\
\text { of } \mathrm{NH}_{4} \mathrm{NO}_{3}\end{array}$ \\
\hline AM3N & Monthly & Yes & Yes & $\mathrm{SO}_{4}^{2-}$ \\
AM3N_fdep & Monthly & Yes & Yes & $\mathrm{HNO}_{3}$ \\
AM3N_diu & Monthly + diurnal & Yes & Yes & $\mathrm{SO}_{4}^{2-}$ \\
AM3N_ns & No & Yes & Yes & $\mathrm{SO}_{4}^{2-}$ \\
AM3N_nhet & Monthly & Yes & No & $\mathrm{SO}_{4}^{2-}$ \\
AM3N_ndust & Monthly & No & Yes & $\mathrm{SO}_{4}^{2-}$ \\
AM3N_fdep_diu & Monthly+diurnal & Yes & Yes & $\mathrm{HNO}_{3}$ \\
\hline
\end{tabular}

\subsubsection{Surface removal of fine $\mathrm{NO}_{3}^{-}$}

In $\mathrm{AM} 3 \mathrm{~N}$, the dry deposition of $\mathrm{NH}_{4} \mathrm{NO}_{3}$ is slow, similar to other fine aerosols. Several field observations have reported steeper vertical gradients and faster deposition velocities $\left(v_{\mathrm{d}}\right)$ for $\mathrm{NO}_{3}^{-}$than for $\mathrm{SO}_{4}^{2-}$ (Huebert et al., 1988; Wyers and Duyzer, 1997; Van Oss et al., 1998; Rattray and Sievering, 2001; Nemitz et al., 2004; Fowler et al., 2009; Wolff et al., 2010; Barbaro et al., 2015). This difference stems from gradients in temperature, $\mathrm{RH}$, and $\mathrm{HNO}_{3}$ within the boundary layer, which reduce the stability of $\mathrm{NH}_{4} \mathrm{NO}_{3}$ near the surface. The volatilization of $\mathrm{NH}_{4} \mathrm{NO}_{3}$ may result in an underestimate of the surface deposition of $\mathrm{TNO}_{3} \equiv \mathrm{HNO}_{3}+\mathrm{NO}_{3}^{-}$, since $v_{\mathrm{d}}\left(\mathrm{NH}_{4} \mathrm{NO}_{3}\right) \ll v_{\mathrm{d}}\left(\mathrm{HNO}_{3}\right)$. As an upper bound, we assume that the surface removal of fine $\mathrm{NO}_{3}^{-}$is limited by turbulent transport by setting $v_{\mathrm{d}}\left(\mathrm{NO}_{3}^{-}\right)=v_{\mathrm{d}}\left(\mathrm{HNO}_{3}\right)$ in AM3N_fdep.

\subsection{Budget and global distribution}

Table 1 shows the budgets of $\mathrm{SO}_{4}^{2-}, \mathrm{NH}_{x}$, and $\mathrm{NO}_{y}$ in $\mathrm{AM} 3$ and $\mathrm{AM} 3 \mathrm{~N}$ for 2010. Here $\mathrm{NO}_{y}$ is defined as the sum of all species that contained oxidized nitrogen. The budgets for all simulations are given in Table $\mathrm{S} 2$.

The lifetimes of $\mathrm{SO}_{4}^{2-}, \mathrm{NH}_{x}$, and $\mathrm{NO}_{y}$ are significantly shorter in $\mathrm{AM} 3 \mathrm{~N}$ than in $\mathrm{AM} 3$. This decrease is driven in part by greater convective removal associated with changes in finer vertical discretization of convective plumes. For instance, the lifetime of $\mathrm{SO}_{4}^{2-}$ with respect to convective removal decreases from 44 to 18 days.

For $\mathrm{SO}_{4}^{2-}$, the increased effectiveness of convective removal is partly offset by reduction in the removal by snow (Sect. 2.2). The $\mathrm{SO}_{4}^{2-}$ lifetime in both AM3 and AM3N falls within the range of AEROCOM models (3-5.2 days Schulz et al., 2006). Unlike AM3, AM3N includes ammonium in the calculation of cloud $\mathrm{pH}$, which reduces the acidity of cloud droplets and favors the production of $\mathrm{SO}_{4}^{2-}$ via in-cloud oxidation of $\mathrm{SO}_{2}$ by $\mathrm{O}_{3}$. The production of $\mathrm{SO}_{4}^{2-}$ via $\mathrm{SO}_{2}+\mathrm{O}_{3}$ is $4.5 \mathrm{Tg} \mathrm{S} \mathrm{a}^{-1}$ in AM3N, greater than the recent estimate of Sofen et al. (2011) (1.5 Tg S a $\left.{ }^{-1}\right)$. This discrepancy may reflect differences in cloud $\mathrm{pH}$ and lower $\mathrm{H}_{2} \mathrm{O}_{2}$ concentrations in $\mathrm{AM} 3 \mathrm{~N}$ because of faster dry deposition for $\mathrm{H}_{2} \mathrm{O}_{2}$ and effi- cient removal of $\mathrm{HO}_{2}$ via aerosol uptake (Mao et al., 2013a). AM3N does not include production of $\mathrm{SO}_{4}^{2-}$ via the aqueous reaction of $\mathrm{SO}_{2}$ with $\mathrm{O}_{2}$ catalyzed by iron and manganese or by the oxidation of $\mathrm{SO}_{2}$ by stabilized Criegee intermediates (Mauldin III et al., 2012). The lifetime of $\mathrm{SO}_{2}$ is 1.3 days in both AM3 and AM3N, similar to Sofen et al. (2011) and Lee et al. (2011). The overall conversion from $\mathrm{SO}_{2}$ to $\mathrm{SO}_{4}^{2-}$ (excluding $\mathrm{SO}_{4}^{2-}$ on dust) is reduced compared to AM3 from 50 to $42 \%$ and lower than the AEROCOM multi-model mean (62\%).

In $\mathrm{AM} 3, \mathrm{NH}_{3}$ uptake by $\mathrm{SO}_{4}^{2-}$ is solely controlled by kinetics without any thermodynamic limit, such that $\mathrm{NH}_{3}$ burden is small $(0.005 \mathrm{TgN})$ and $\mathrm{NH}_{3}$ generally limits the formation of $\mathrm{NH}_{4} \mathrm{NO}_{3}$. In $\mathrm{AM} 3 \mathrm{~N}$, the uptake of $\mathrm{NH}_{3}$ by $\mathrm{SO}_{4}^{2-}$ aerosols cannot exceed the thermodynamic limit calculated by ISORROPIA, which results in a greater $\mathrm{NH}_{3}$ burden $(0.11$ $\mathrm{TgN}$ ) and favors the production of $\mathrm{NH}_{4} \mathrm{NO}_{3}$. The shorter lifetime of $\mathrm{NH}_{x}$ in $\mathrm{AM} 3 \mathrm{~N}$ than in AM3 reflects the change in the speciation of $\mathrm{NH}_{x}$ and the faster dry deposition of $\mathrm{NH}_{3}$ relative to $\mathrm{NH}_{4}^{+}$. The lifetime of $\mathrm{NH}_{x}$ in AM3N (2.5 days) is similar to that derived by $\mathrm{Xu}$ and Penner (2012) and Hauglustaine et al. (2014) (2.3 days).

AM3N and AM3 differ most strikingly in their simulations of $\mathrm{NO}_{y}$. The contribution of $\mathrm{HNO}_{3}$ to the removal of $\mathrm{NO}_{y}$ decreases from $81 \%$ (AM3) to $56 \%$ (AM3N). In contrast, the contribution of aerosols to $\mathrm{NO}_{y}$ removal increases from 2 to $22 \%$. Recent studies (Hauglustaine et al., 2014; Xu and Penner, 2012) have found an even greater contribution of aerosols to the removal of $\mathrm{NO}_{y}(>30 \%)$; this difference may reflect the lack of $\mathrm{HNO}_{3}$ uptake by sea salt in AM3N. Organic nitrogen contributes $10 \%$ of $\mathrm{NO}_{y}$ removal in both AM3 and AM3N. The much lower fraction of $\mathrm{NO}_{y}$ deposited as $\mathrm{HNO}_{3}$ in $\mathrm{AM} 3 \mathrm{~N}$ relative to AM3 reflects both the increased production of $\mathrm{NH}_{4} \mathrm{NO}_{3}$ and the uptake of $\mathrm{HNO}_{3}$ on dust. The total heterogeneous production of $\mathrm{HNO}_{3}$ by $\mathrm{N}_{2} \mathrm{O}_{5}$ (9.7 $\left.\mathrm{TgNa}^{-1}\right), \mathrm{NO}_{2}\left(0.6 \mathrm{TgNa}^{-1}\right)$, and $\mathrm{NO}_{3}^{-}\left(0.4 \mathrm{TgNa}^{-1}\right)$ uptake on fine aerosols is reduced by $50 \%$ in $\mathrm{AM} 3 \mathrm{~N}$ relative to AM3. This decrease is primarily driven by reduced reaction probabilities for $\mathrm{NO}_{2}$ and $\mathrm{NO}_{3}$ uptake. In contrast, the change of $\gamma_{\mathrm{N}_{2} \mathrm{O}_{5}}$ from 0.1 (AM3) to 0.01 (AM3N) reduces the heterogeneous uptake of $\mathrm{N}_{2} \mathrm{O}_{5}$ by only $20 \%$ because of 


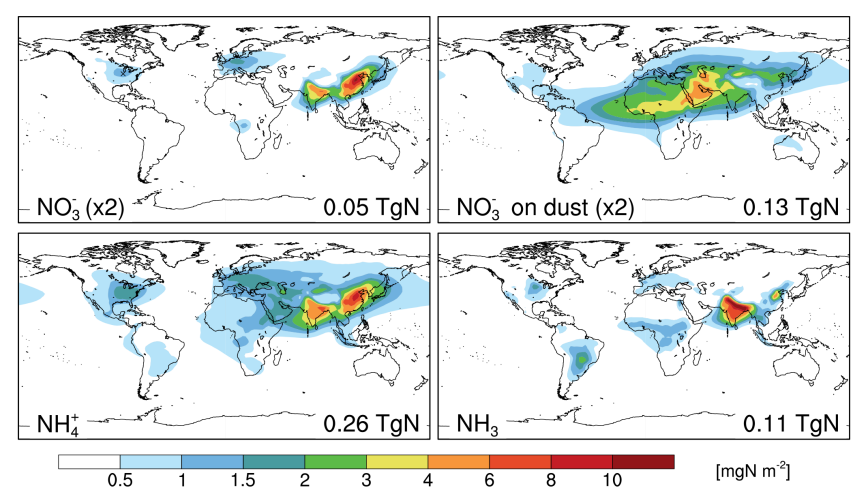

Figure 2. Annual mean burden of $\mathrm{NO}_{3}^{-}, \mathrm{NO}_{3}^{-}$on dust, $\mathrm{NH}_{4}^{+}$, and $\mathrm{NH}_{3}$ in $\mathrm{mg} \mathrm{Nm}^{-2}$ in AM3N from 2008 to 2010. Global burdens are indicated inset. The location of the Bondville site is indicated by a black cross in the upper left panel.

the large increase in the sulfate surface area in winter (see Sect. 3). The magnitude of the $\mathrm{N}_{2} \mathrm{O}_{5}$ source of $\mathrm{HNO}_{3}$ in AM3N is 3 times as large as reported by Hauglustaine et al. (2014). This may reflect greater reactive aerosol surface area in $\mathrm{AM} 3 \mathrm{~N}$, as $\mathrm{N}_{2} \mathrm{O}_{5}$ hydrolysis can take place on $\mathrm{SO}_{4}^{2-}, \mathrm{BC}$, $\mathrm{OC}$, and $\mathrm{NO}_{3}^{-}$aerosols, while only $\mathrm{SO}_{4}^{2-}$ is considered by Hauglustaine et al. (2014). Reduction in the simulated $\mathrm{HNO}_{3}$ burden - driven by faster $\mathrm{NO}_{3}^{-}$deposition (AM3N_fdep), heterogeneous uptake of $\mathrm{HNO}_{3}$ on dust (AM3N_ndust), or reduced heterogeneous production of $\mathrm{HNO}_{3}$ (AM3N_nhet) - increase cloud $\mathrm{pH}$, which favors the oxidation of $\mathrm{SO}_{2}$ by $\mathrm{O}_{3}$ (Table S2).

Figure 2 shows the burden of fine $\mathrm{NO}_{3}^{-}, \mathrm{NO}_{3}^{-}$on dust, $\mathrm{NH}_{4}^{+}$, and $\mathrm{NH}_{3}$ in $\mathrm{AM} 3 \mathrm{~N}$. The simulated global burdens fall within the range of previous estimates (Bauer et al., 2007; Feng and Penner, 2007; Pye et al., 2009; Pringle et al., 2010; Bellouin et al., 2011; Xu and Penner, 2012; Hauglustaine et al., 2014) for fine $\mathrm{NO}_{3}^{-}(0.04-0.11 \mathrm{TgN}), \mathrm{NO}_{3}^{-}$on dust $(0.07-0.41 \mathrm{TgN}), \mathrm{NH}_{4}^{+}(0.21-0.27 \mathrm{TgN})$, and $\mathrm{NH}_{3}(0.07-$ $0.29 \mathrm{Tg} \mathrm{N}$ ). The burden of fine $\mathrm{NO}_{3}^{-}$peaks over China where it reaches over $5 \mathrm{mg} \mathrm{N} \mathrm{m}^{-2}$, with a secondary maximum over India. Fine $\mathrm{NO}_{3}^{-}$burden is also elevated over northern Europe and the US Midwest, where agricultural activities are located close to large sources of oxidized nitrogen. Compared with the fine nitrate distribution from Hauglustaine et al. (2014) for 2000, AM3N simulates greater nitrate burden over Asia but lower burdens over Europe and the USA. These differences may reflect different spatial distributions of $\mathrm{NH}_{3}$ emissions (Fig. 1). AM3N simulates large enhancements in $\mathrm{NH}_{3}$ column over source regions such as India (where the burden reaches $12 \mathrm{mg} \mathrm{m}^{-2}$ ), northern China, the Netherlands, and the US Midwest, as supported by satellite observations (Van Damme et al., 2014a). This lends some support to the spatial allocation of anthropogenic $\mathrm{NH}_{3}$ emissions in HTAP_v2 inventory, although observed enhance-
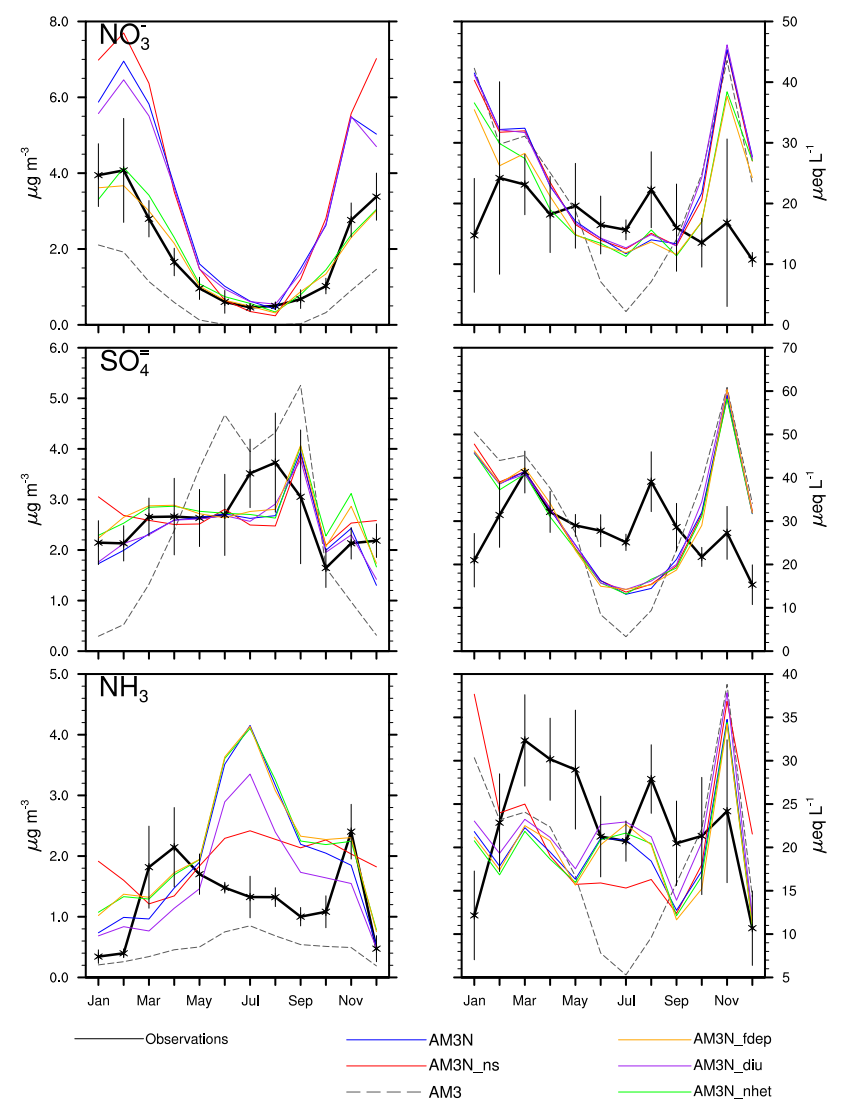

Figure 3. Observed (black) and simulated monthly concentrations of $\mathrm{NO}_{3}^{-}, \mathrm{SO}_{4}^{2-}$, and $\mathrm{NH}_{3}$ at Bondville $\left(40.1^{\circ} \mathrm{N}, 88.4^{\circ} \mathrm{W}\right)$ in surface air (left panel) and precipitated water (right panel). Observations are averaged from 2006 to 2012, while model output is from 2008 to 2010. The vertical bars denote 1 standard deviation of the mean monthly observations. The different model sensitivity experiments are described in Table 2.

ments in $\mathrm{NH}_{3}$ burden over the Po Valley and California are not captured by AM3N.

\section{Evaluation}

\subsection{Bondville}

We first evaluate the model against an extensive suite of observations collected at Bondville $\left(40.1^{\circ} \mathrm{N}, 88.4^{\circ} \mathrm{W}\right.$; 213 ma.s.l.). Bondville is located in the vicinity of large sources of $\mathrm{NH}_{3}$ and $\mathrm{NO}_{x}$, which result in elevated surface $\mathrm{NO}_{3}^{-}$concentrations (Fig. 3) and make this site wellsuited to evaluate the representation of nitrate aerosols in AM3 and AM3N. Here we compare the model against observations of surface $\mathrm{NO}_{3}^{-}$and $\mathrm{SO}_{4}^{2-}$ concentrations (from the Interagency Monitoring of Protected Visual Environments (IMPROVE) network), surface $\mathrm{NH}_{3}$ concentrations (Ammonia Monitoring Network (AMoN)), $\mathrm{SO}_{4}^{2-}, \mathrm{NO}_{3}^{-}$, and $\mathrm{NH}_{4}^{+}$wet deposition (National Atmospheric Deposition Pro- 
gram (NADP)), surface dry aerosol extinction (NOAA Earth System Research Laboratory (ESRL), Delene and Ogren, 2002), and AOD (Aerosol Robotic Network (AERONET)). Vertical profiles of aerosol extinction were also collected by NOAA ESRL Airborne Aerosol Observing (AAO) program from 2006 to 2009 (Esteve et al., 2012; Sheridan et al., 2012). Temperature and humidity profiles are measured twice daily by the ESRL Surface Radiation Budget Network (SURFRAD).

Figure 3 shows the observed (black) and simulated monthly concentrations in surface air (left column) and in precipitated water (right column) for $\mathrm{NO}_{3}^{-}, \mathrm{SO}_{4}^{2-}$, and $\mathrm{NH}_{3}$ ( $\mathrm{NH}_{4}^{+}$for wet deposition) for AM3 and different AM3N configurations. Both $\mathrm{NO}_{3}^{-}$and $\mathrm{NH}_{3}$ concentrations are higher year round in AM3N than in AM3, as ISORROPIA enforces thermodynamic limitation on the uptake of $\mathrm{NH}_{3}$ by $\mathrm{SO}_{4}^{2-}$. Observations show a spring peak in surface $\mathrm{NH}_{3}$ concentrations, while both AM3 and AM3N simulate a summer peak. Bondville is surrounded by corn and soybean fields and $\mathrm{NH}_{3}$ emissions associated with spring fertilizer application may be underestimated (Paulot et al., 2014). In summer, more efficient convective removal of $\mathrm{SO}_{4}^{2-}$ in $\mathrm{AM} 3 \mathrm{~N}$ reduces the AM3 high bias for $\mathrm{SO}_{4}^{2-}$ surface concentration and low bias for $\mathrm{SO}_{4}^{2-}$ wet deposition. In winter, the low bias for surface $\mathrm{SO}_{4}^{2-}$ concentration in AM3 is reduced as a result of less efficient removal by snow and increased in-cloud oxidation of $\mathrm{SO}_{2}$. AM3N_nhet and AM3N_fdep produce greater $\mathrm{SO}_{4}^{2-}$ concentrations in winter than $\mathrm{AM} 3 \mathrm{~N}$ consistent with increased in-cloud oxidation of $\mathrm{SO}_{2}$ by $\mathrm{O}_{3}$ (Table $\mathrm{S} 2$ ).

$\mathrm{NO}_{3}^{-}$shows a large positive bias in AM3N in winter ( $>70 \%$ in February). This bias can be reduced by either neglecting the heterogeneous production of $\mathrm{HNO}_{3}$ via $\mathrm{NO}_{2}$, $\mathrm{NO}_{3}$, and $\mathrm{N}_{2} \mathrm{O}_{5}$ (AM3N_nhet) or treating the deposition of fine $\mathrm{NO}_{3}^{-}$like that of $\mathrm{HNO}_{3}$ (AM3N_fdep). Conversely, neglecting the seasonality of $\mathrm{NH}_{3}$ emissions (AM3N_ns), similar to simulations performed for ACCMIP and CMIP5, increases the bias for $\mathrm{NO}_{3}^{-}$in winter.

To analyze the factors controlling $\mathrm{NH}_{4} \mathrm{NO}_{3}$ in the model, we calculate the gas ratio (GR) at each model time step. The GR was first proposed by Ansari and Pandis (1998) to diagnose the sensitivity of $\mathrm{NH}_{4} \mathrm{NO}_{3}$ to its gas-phase precursors $\mathrm{NH}_{3}$ and $\mathrm{HNO}_{3}$ and is defined as

$\mathrm{GR}=\frac{\left[\mathrm{NH}_{3}\right]+\left[\mathrm{NH}_{4}^{+}\right]-2\left[\mathrm{SO}_{4}^{2-}\right]}{\left[\mathrm{HNO}_{3}\right]+\left[\mathrm{NO}_{3}^{-}\right]}$.

GR defines three different regimes: (a) GR $>1$, in which $\mathrm{NH}_{4} \mathrm{NO}_{3}$ formation is limited by the availability of $\mathrm{HNO}_{3}$, (b) $0<\mathrm{GR}<1$, in which $\mathrm{NH}_{4} \mathrm{NO}_{3}$ is limited by the availability of $\mathrm{NH}_{3}$, and (c) $\mathrm{GR}<0$, in which $\mathrm{NH}_{4} \mathrm{NO}_{3}$ is inhibited by $\mathrm{SO}_{4}^{2-}$. We define the degree of limitation of $\mathrm{NH}_{4} \mathrm{NO}_{3}$ by $\mathrm{HNO}_{3}\left(\mathcal{L}\left(\mathrm{HNO}_{3}\right)\right)$ as the fraction of the time when $\mathrm{GR}>1$. In winter, $\mathrm{NH}_{4} \mathrm{NO}_{3}$ is most frequently limited by $\mathrm{HNO}_{3}\left(\mathcal{L}\left(\mathrm{HNO}_{3}\right)\right)=78 \%$ in AM3N). Figure 4 (bottom panel) shows $\mathcal{L}\left(\mathrm{HNO}_{3}\right)$ binned by $\mathrm{NO}_{3}^{-}$concentra-

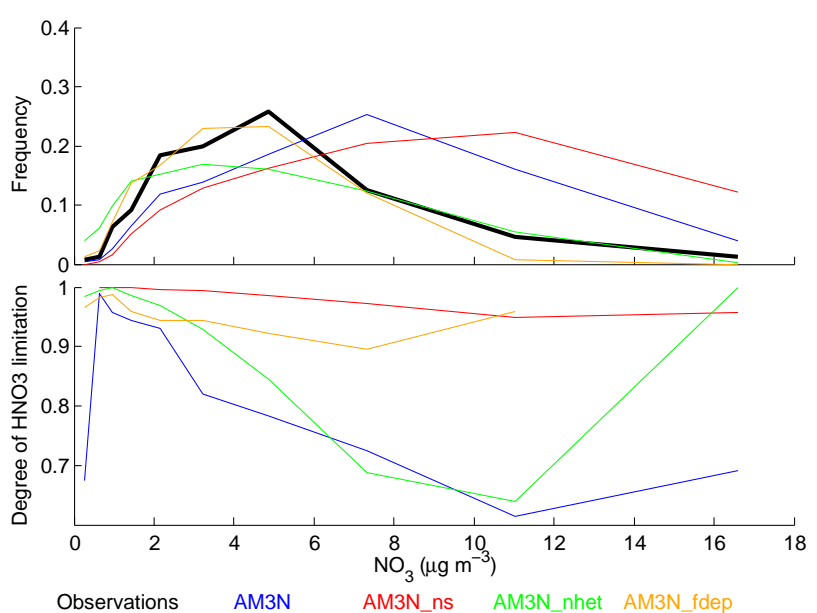

Figure 4. Observed and simulated distribution of daily $\mathrm{NO}_{3}^{-}$concentration at Bondville $\left(40.1^{\circ} \mathrm{N}, 88.4^{\circ} \mathrm{W}\right.$ ) in winter (top panel) from 2006 to 2012 (observations) and 2008 to 2010 (model). The degree of $\mathrm{HNO}_{3}$ limitation for $\mathrm{NH}_{4} \mathrm{NO}_{3}$ formation $(\mathrm{GR}>1)$ is shown in the bottom panel. The different model sensitivity experiments are described in Table 2.

tions. $\mathrm{NH}_{4} \mathrm{NO}_{3}$ is most limited by $\mathrm{HNO}_{3}$ availability at low $\left[\mathrm{NO}_{3}^{-}\right]$, while $\mathrm{NH}_{3}$ becomes more limiting at high $\left[\mathrm{NO}_{3}^{-}\right]$. This suggests that even in an environment that is generally $\mathrm{NH}_{3}$-rich with respect to $\mathrm{NH}_{4} \mathrm{NO}_{3}$ formation, $\mathrm{NH}_{3}$ emissions modulates $\mathrm{NO}_{3}^{-}$production during high $\mathrm{NO}_{3}^{-}$episodes (AM3N_ns).

Figure 4 also shows that AM3N_nhet and AM3N_fdep produce different distributions of daily $\left[\mathrm{NO}_{3}^{-}\right]$although they have similar mean monthly $\left[\mathrm{NO}_{3}^{-}\right]$(top panel). AM3N_fdep reproduces observations at low $\mathrm{NO}_{3}^{-}$concentrations well but underestimates the frequency of high $\mathrm{NO}_{3}^{-}$events, when $\mathrm{NH}_{4} \mathrm{NO}_{3}$ exhibits significant sensitivity to $\mathrm{NH}_{3}$. Under these conditions, less volatilization of $\mathrm{NH}_{4} \mathrm{NO}_{3}$ near the surface is expected as $\mathrm{NH}_{3}$ is not depleted near the surface like $\mathrm{HNO}_{3}$. AM3_nhet $\left[\mathrm{NO}_{3}^{-}\right]$is most consistent with observations at high $\left[\mathrm{NO}_{3}^{-}\right]$, conditions under which $\mathrm{N}_{2} \mathrm{O}_{5}$ heterogeneous uptake has been observed to be inhibited both in laboratory and field settings (Bertram and Thornton, 2009; Wagner et al., 2013). The ability of AM3N_fdep and AM3N_nhet to capture $\mathrm{NO}_{3}^{-}$under different conditions emphasizes the need to represent the dynamic nature of $\gamma\left(\mathrm{N}_{2} \mathrm{O}_{5}\right)$ and $\mathrm{TNO}_{3}$ surface removal.

Figure 5 shows the observed and simulated monthly AOD at Bondville. Observed AOD peaks in summer and reaches a minimum in winter. This seasonality is well captured by AM3 (top panel), while AOD in AM3N_fdep_diu (bottom panel) peaks in spring and is biased high in winter and fall. Biases in AOD may be caused by errors in aerosol abundance and speciation but also by errors in aerosol hygroscopic growth. Their relative contribution can be estimated by comparing observed and simulated aerosol extinction pro- 


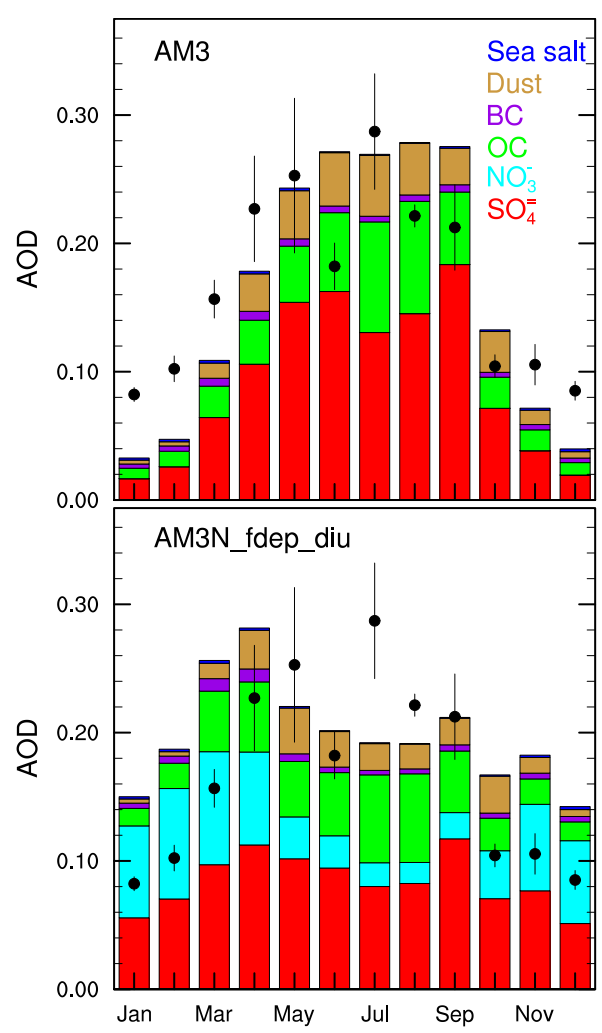

Figure 5. Observed and simulated aerosol optical depth at $550 \mathrm{~nm}$ at Bondville $\left(40.1^{\circ} \mathrm{N}, 88.4^{\circ} \mathrm{W}\right)$ in AM3 and AM3N_fdep_diu. Observations (black crosses) are averaged from 2006 to 2012 and the thin vertical black bars denote 1 standard deviation of the mean. Thick color bars show the simulated optical depth of $\mathrm{SO}_{4}^{2-}$ (red), $\mathrm{NO}_{3}^{-}$(cyan), OC (green), BC (purple), dust (brown), and sea salt (blue) for AM3N_fdep_diu (2008-2010 average).

files, under dry conditions $(\mathrm{RH}<40 \%)$ (Delene and Ogren, 2002; Sheridan et al., 2012; Esteve et al., 2012). Figure 6 shows that AM3N overestimates aerosol dry extinction in spring and fall, which suggests that the simulated aerosol abundance is overestimated. This bias may be caused by organic carbon or dust, which contribute over $30 \%$ of the simulated aerosol dry extinction throughout the column in spring, summer, and fall (Fig. S2 in the Supplement). In winter and summer, AM3N is more consistent with the observed aerosol dry extinction profile than AM3. In particular, AM3 exhibits a low bias in winter and a high bias in summer, consistent with the biases for surface $\left[\mathrm{SO}_{4}^{2-}\right]$ and with the lack of extinction from $\mathrm{NO}_{3}^{-}$, the largest contributor to AM3N dry aerosol extinction below $1000 \mathrm{~m}$ in winter (Fig. S2). The different biases of AM3 and AM3N against AOD and dry extinction in winter and summer suggest errors in the hygroscopic growth of aerosols. This is consistent with comparisons with twice daily soundings of temperature (Fig. S3) and relative humidity (Fig. S4) over Bondville, which show that $\mathrm{AM} 3 \mathrm{~N}$ is on average too humid in winter and spring and too dry in summer. In particular, AM3N overestimates the
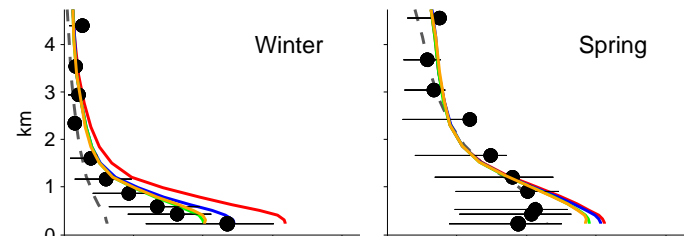

Observations

АM3

AM3N_ns

AM3N

AM3N_nhet AM3N_fdep
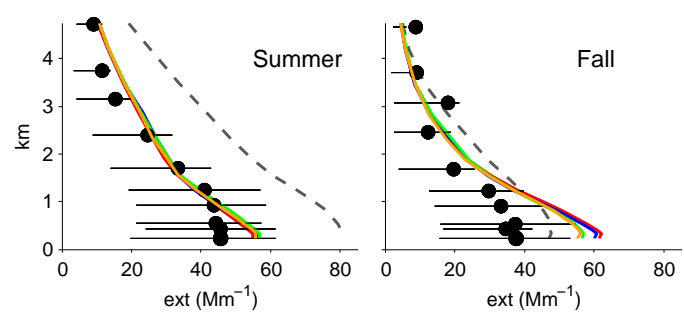

Figure 6. Mean seasonal observed (black dots) and simulated surface and vertical profiles of aerosol dry extinction at Bondville $\left(40.1^{\circ} \mathrm{N}, 88.4^{\circ} \mathrm{W}\right)$. The vertical profile show the average of all observations by the Airborne Aerosol Observatory from 2006 to 2009 collected during daytime (10:00-16:00 local time). Surface observations reflect the average of all daytime observations at the ESRL BND station from 2006 to 2012 with no local pollution. The model is averaged for daytime from 2008 to 2010 . Horizontal lines show the 25th to 75th percentiles of observed dry aerosol extinctions. Dry extinctions are reported at standard temperature and pressure $(273.15 \mathrm{~K}, 1 \mathrm{~atm})$. We multiply the modeled nitrate extinction by 0.8 to account for the evaporation of ammonium nitrate in the nephelometer (Bergin et al., 1997). The different model sensitivity experiments are described in Table 2.

occurrence of high-humidity periods (RH $>90 \%$, Fig. S5), when aerosol hygroscopic growth is especially large. Modeled AOD would be especially sensitive to positive RH biases in winter since AOD winter is primarily controlled by $\mathrm{SO}_{4}^{2-}$ and $\mathrm{NO}_{3}^{-}$, which have stronger hygroscopic growth than organic carbon and dust.

\subsection{Global evaluation}

We broaden our evaluations of AM3 and AM3N using observations of surface $\left[\mathrm{NO}_{3}^{-}\right],\left[\mathrm{SO}_{4}^{2-}\right]$, and $\left[\mathrm{NH}_{3}\right]$ in the USA (IMPROVE and AMoN) and Europe (European Monitoring and Evaluation Programme (EMEP)), $\left[\mathrm{NH}_{x}\right]$ and $\left[\mathrm{HNO}_{3}\right]$ (EMEP), and $\mathrm{SO}_{4}^{2-}, \mathrm{NO}_{3}^{-}$, and $\mathrm{NH}_{4}^{+}$concentrations in precipitated water (NADP and EMEP). We compare the model monthly means from 2008 to 2010 to the average monthly observations from 2006 to 2012. For AMoN, we consider all observations (2007-2014) to take advantage of the ongoing expansion of the network. We apply Grubbs' test (Grubbs, 1950) for each station to filter out possible outliers $(95 \%$ critical value). Table 3 shows the normalized mean bias (ratio of the mean difference between the model and observations to the mean observed value) and the correlation between the model and observations for each data set for AM3, AM3N. Evaluations of all AM3N configurations and seasonal com- 
Table 3. Normalized mean bias and correlation coefficient (in parentheses) of monthly model results vs. measurements of surface concentrations of $\mathrm{SO}_{4}^{2-}, \mathrm{NO}_{3}^{-}$and $\mathrm{HNO}_{3}, \mathrm{NH}_{3}$ and $\mathrm{NH}_{x}$, concentrations of $\mathrm{SO}_{4}^{2-}, \mathrm{NH}_{4}^{+}$, and $\mathrm{NO}_{3}^{-}$in rain, and total aerosol optical depth at $550 \mathrm{~nm}$ from AERONET, MISR, and MODIS*.

\begin{tabular}{|c|c|c|c|c|c|}
\hline & & & AM3 & AM3N & AM3N_fdep_diu \\
\hline \multicolumn{6}{|l|}{$\mathrm{SO}_{4}^{2-}$} \\
\hline & \multicolumn{5}{|l|}{ Aerosol } \\
\hline & & USA & $0.07(0.81)$ & $-0.11(0.89)$ & $-0.06(0.89)$ \\
\hline & & Europe & $-0.43(0.24)$ & $-0.22(0.62)$ & $-0.13(0.64)$ \\
\hline & \multicolumn{5}{|c|}{ Wet deposition } \\
\hline & & USA & $0.00(0.42)$ & $-0.07(0.59)$ & $-0.08(0.57)$ \\
\hline & & Europe & $-0.18(0.53)$ & $-0.32(0.57)$ & $-0.32(0.53)$ \\
\hline \multirow{2}{*}{\multicolumn{6}{|c|}{$\mathrm{NO}_{3}^{-}$}} \\
\hline & & & & & \\
\hline & & USA & $-0.61(0.64)$ & $1.03(0.64)$ & $0.17(0.65)$ \\
\hline & & Europe & $-0.78(0.62)$ & $0.32(0.62)$ & $-0.30(0.58)$ \\
\hline & \multicolumn{5}{|c|}{ Gas + aerosol } \\
\hline & & Europe & $-0.18(0.61)$ & $0.17(0.75)$ & $-0.29(0.57)$ \\
\hline & \multicolumn{5}{|c|}{ Wet deposition } \\
\hline & & USA & $0.14(0.33)$ & $0.23(0.52)$ & $0.11(0.54)$ \\
\hline & & Europe & $-0.32(0.57)$ & $-0.29(0.54)$ & $-0.39(0.54)$ \\
\hline \multirow{2}{*}{\multicolumn{6}{|c|}{$\mathrm{NH}_{x}$}} \\
\hline & & & & & \\
\hline & & USA & $-0.75(0.50)$ & $-0.10(0.54)$ & $-0.22(0.53)$ \\
\hline & & Europe & $-0.65(0.48)$ & $0.23(0.54)$ & $0.17(0.50)$ \\
\hline & \multicolumn{5}{|c|}{ Gas + aerosol } \\
\hline & & Europe & $0.69(0.66)$ & $0.18(0.64)$ & $0.02(0.64)$ \\
\hline & \multicolumn{5}{|c|}{ Wet deposition } \\
\hline & & USA & $-0.20(0.50)$ & $-0.20(0.69)$ & $-0.15(0.69)$ \\
\hline & & Europe & $-0.23(0.52)$ & $-0.36(0.58)$ & $-0.32(0.58)$ \\
\hline \multicolumn{6}{|l|}{ AOD } \\
\hline & \multicolumn{5}{|l|}{ MODIS } \\
\hline & & World & $0.09(0.57)$ & $-0.08(0.68)$ & $-0.08(0.68)$ \\
\hline & & High $\mathrm{NO}_{3}^{-}$ & $-0.15(0.83)$ & $0.11(0.87)$ & $0.09(0.87)$ \\
\hline & & High $\mathrm{SO}_{4}^{2-}$ & $0.57(0.83)$ & $0.06(0.87)$ & $0.06(0.87)$ \\
\hline & \multicolumn{5}{|l|}{ MISR } \\
\hline & & World & $-0.03(0.53)$ & $-0.16(0.59)$ & $-0.16(0.59)$ \\
\hline & & High $\mathrm{NO}_{3}^{-}$ & $-0.12(0.84)$ & $0.21(0.87)$ & $0.18(0.87)$ \\
\hline & & High $\mathrm{SO}_{4}^{2-}$ & $0.54(0.86)$ & $0.12(0.88)$ & $0.12(0.88)$ \\
\hline & \multicolumn{5}{|c|}{ AERONET } \\
\hline & & World & $-0.03(0.72)$ & $-0.10(0.82)$ & $-0.11(0.82)$ \\
\hline & & High $\mathrm{NO}_{3}^{-}$ & $-0.50(0.87)$ & $-0.01(0.76)$ & $-0.07(0.70)$ \\
\hline & & $\mathrm{High} \mathrm{SO}_{4}^{2-}$ & $0.33(0.47)$ & $-0.10(0.74)$ & $-0.10(0.71)$ \\
\hline
\end{tabular}

* Model results are averaged from 2008 to 2010, while we use observations from 2006 to 2012, except for MODIS and MISR (2008-2010) and $\mathrm{NH}_{3}$ observations in the USA (2007-2014). Detailed seasonal comparisons are presented in the Supplement.

parisons (Table S3 and Figs. S6 to S18) are provided in the Supplement.

Table 3 shows that AM3 and AM3N exhibit similar normalized mean biases for $\mathrm{SO}_{4}^{2-}$ surface concentrations and wet deposition in the USA and Europe. However, AM3N exhibits better correlation with observations, which reflects a large improvement in the simulated seasonality of surface
$\mathrm{SO}_{4}^{2-}$ (Figs. S6 and S12). As previously noted, the improvement in the simulated $\left[\mathrm{SO}_{4}^{2-}\right]$ in $\mathrm{AM} 3 \mathrm{~N}$ reflects increased removal in summer by convective precipitation, greater production of $\mathrm{SO}_{4}^{2-}$ via $\mathrm{O}_{3}+\mathrm{SO}_{2}$, and less efficient removal by snow in winter. The increased removal of $\mathrm{SO}_{4}^{2-}$ by convective precipitation in $\mathrm{AM} 3 \mathrm{~N}$ improves the simulation of summer wet deposition in the USA, although it remains bi- 


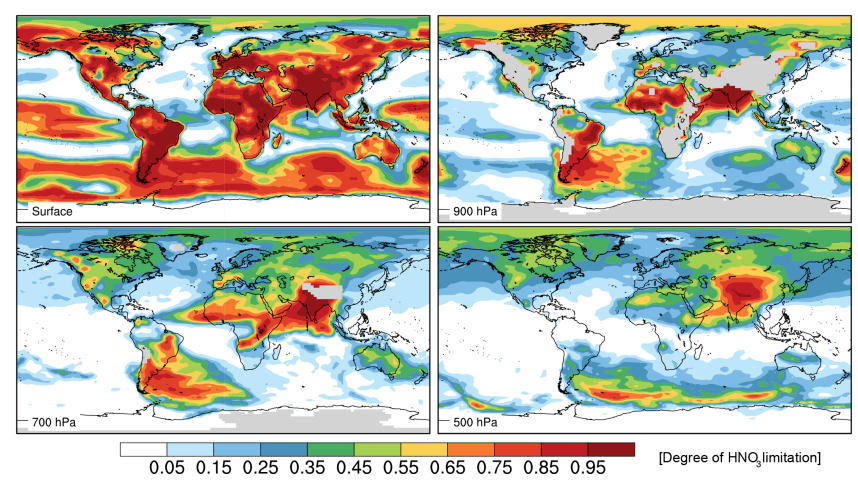

Figure 7. Simulated degree of limitation of $\mathrm{NH}_{4} \mathrm{NO}_{3}$ formation by $\mathrm{HNO}_{3}(\mathrm{GR}>1)$ weighted by $\mathrm{NH}_{4} \mathrm{NO}_{3}$ concentration at different pressure levels in AM3N for 2010.

ased low (Fig. S9). Increased convective removal of $\mathrm{HNO}_{3}$ and $\mathrm{NH}_{3}$ also reduces the low bias in simulated summer wet deposition for $\mathrm{NO}_{3}^{-}\left(-50\right.$ to $-23 \%$, Fig. S10) and $\mathrm{NH}_{4}^{+}$ ( -46 to $-16 \%$, Fig. S10). Greater in-cloud oxidation of $\mathrm{SO}_{2}$ by ozone in AM3N_fdep and AM3N_nhet reduces the low biases for surface $\left[\mathrm{SO}_{4}^{2-}\right]$ relative to $\mathrm{AM} 3 \mathrm{~N}$ (from -11 to $-5 \%$ in the USA and -22 to $-13 \%$ in Europe).

Surface $\left[\mathrm{NO}_{3}^{-}\right]$is generally overestimated in AM3N, especially over the USA $(+100 \%)$. Recent studies using a range of $\mathrm{NH}_{3}$ emissions and different representations of aerosol thermodynamics and heterogeneous chemistry have also found large positive biases in simulated surface $\left[\mathrm{NO}_{3}^{-}\right]$ (Heald et al., 2012; Walker et al., 2012; Hauglustaine et al., 2014). Figure 7 shows the annual distribution of $\mathcal{L}\left(\mathrm{HNO}_{3}\right)$ in AM3N. At the surface, $\mathrm{NH}_{4} \mathrm{NO}_{3}$ formation is primarily limited by the availability of $\mathrm{HNO}_{3}$ over continental regions, such as Europe, India, or northern China. Under $\mathrm{HNO}_{3}$ limited conditions, our analysis at Bondville suggests that increasing the deposition of $\mathrm{TNO}_{3}$ (AM3N_fdep) can improve the simulation of surface $\left[\mathrm{NO}_{3}^{-}\right]$. On a continental basis, we also find that AM3N_fdep_diu better captures surface $\left[\mathrm{NO}_{3}^{-}\right]$ $(+17 \%$ bias in the USA) and we will focus on this configuration in the following. Note that the diurnal cycle of $\mathrm{NH}_{3}$ emissions has a small impact on the simulated mean surface $\left[\mathrm{NO}_{3}^{-}\right]$concentration, but reduces surface $\left[\mathrm{NH}_{3}\right]$ and increases its export to the free troposphere. Figure S20 shows the observed and simulated diurnal cycle of $\left[\mathrm{NO}_{3}^{-}\right]$at the YRK site from the SouthEastern Aerosol Research and Characterization Network. $\mathrm{NO}_{3}^{-}$exhibits a pronounced diurnal cycle with a maximum in the early morning and a minimum in the late afternoon (as a result of both thermodynamics and boundary layer height). AM3N and AM3N_diu capture the timing of the diurnal cycle well. $\mathrm{As}^{\mathrm{NH}_{3}}$ emissions peak in the afternoon, the magnitude of the $\mathrm{NH}_{4} \mathrm{NO}_{3}$ diurnal cycle in AM3N_diu is lower than in AM3N. Higher daytime concentrations of $\mathrm{NH}_{4} \mathrm{NO}_{3}$ in AM3N_diu suggest that accounting for the diurnal cycle of $\mathrm{NH}_{3}$ emissions may increase the magnitude of the radiative forcing associated with $\mathrm{NH}_{4} \mathrm{NO}_{3}$.
Figure 8 shows the average monthly variation of AOD from 2008 to 2010 over different regions as observed by MODIS (Remer et al., 2008) and MISR (Kahn et al., 2009) and simulated by AM3 and AM3N_fdep_diu. Although AM3 does not exhibit a large bias on a global scale (normalized mean biases lower than $10 \%$ for both MODIS and MISR), it fails to capture the seasonality of AOD over most continental regions. Over North America, AOD is biased low in winter and high in summer in AM3, consistent with the biases in surface $\left[\mathrm{SO}_{4}^{2-}\right]$. The spring bias may be exacerbated by insufficient transport of aerosols from Asia. AM3 is biased high over tropical land masses, consistent with insufficient convective removal of aerosols. AM3N_fdep_diu AOD shows improved correlations with observations over most continental regions (see also Fig. S19). The increased AOD in winter and spring can be partly attributed to nitrate optical depth, which accounts for over $30 \%$ of AOD over North America.

Following Lee and Adams (2010) and Shindell et al. (2013), we further evaluate the performances of AM3 and AM3N in locations within the top decile of simulated $\mathrm{NO}_{3}^{-}$ and $\mathrm{SO}_{4}^{2-}$ burden against observations from MODIS, MISR, and AERONET. AM3 AOD is biased high over high $\mathrm{SO}_{4}^{2-}$ regions $(+30$ to $50 \%)$ and low over high $\mathrm{NO}_{3}^{-}$regions $(-10$ to $-50 \%$ ) consistent with the analysis of Shindell et al. (2013). The bias over high $\mathrm{SO}_{4}^{2-}$ regions is greatly reduced in AM3N $(<10 \%)$, while the model exhibits a high bias against satellite AOD observations (10-20\%) but little bias against AERONET observations in high $\mathrm{NO}_{3}^{-}$regions. More detailed comparisons with AERONET show that AM3N better captures AOD at high latitudes in spring (Fig. S19), which lends support to the changes made to the representation of incloud sulfate production and wet deposition.

\section{Sensitivity of nitrate optical depth}

\subsection{Present-day emission}

Figure 9 compares the contributions of $\mathrm{SO}_{4}^{2-}, \mathrm{NO}_{3}^{-}$, OC, $\mathrm{BC}$, dust, and sea salt to the global mean AOD in AM3 and AM3N_fdep_diu with previous estimates (Shindell et al., 2013; Hauglustaine et al., 2014). Present-day global mean AOD in AM3N_fdep_diu is $0.136,16 \%$ less than in AM3. All AOD components decrease as a result of more efficient convective removal, with the largest decrease for $\mathrm{SO}_{4}^{2-}$ $(-36 \%) . \mathrm{SO}_{4}^{2-}$ optical depth decreases most from $\mathrm{AM} 3$ to AM3N_fdep_diu over tropical regions, while it increases at high latitudes, consistent with changes in $\mathrm{SO}_{4}^{2-}$ chemistry and removal. $\mathrm{NO}_{3}^{-}$optical depth ranges from 0.0052 (AM3N_nhet) to 0.0078 (AM3N_ndust). Our best estimate is 0.0060 (AM3N_fdep_diu). The different treatment of reactive nitrogen results in similar changes in $\mathrm{SO}_{4}^{2-}(0.002)$ and $\mathrm{NO}_{3}^{-}$optical depth (0.003). The range of $\mathrm{NO}_{3}^{-}$optical depths derived from AM3N (0.0052-0.0078) encompasses 


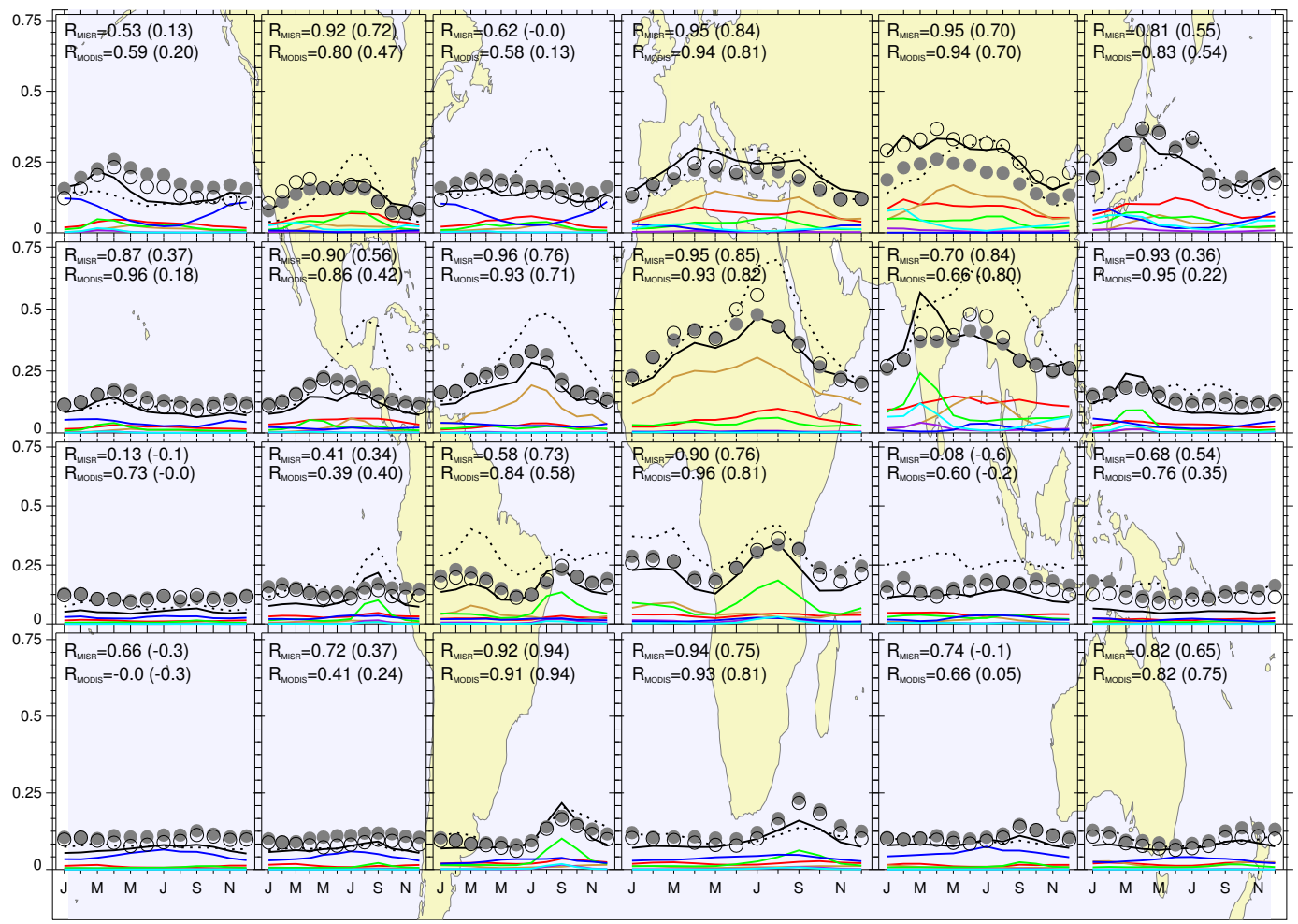

Figure 8. Observed and simulated monthly AOD at $550 \mathrm{~nm}$ in different regions averaged over the 2008-2010 period. Circles show observations from MODIS (open circles) and MISR (filled circles). The solid and dashed black lines show the AOD simulated by AM3N_fdep_diu and AM3 respectively. We also show the simulated optical depths of sulfate (red), nitrate (cyan), dust (brown), organic carbon (green), black carbon (purple), and sea salt (blue) in AM3N_fdep_diu. The model is sampled to match the location and time of valid measurements by both MODIS and MISR in each region. Correlations between simulated and observed AOD are shown inset for AM3N_fdep_diu and AM3 (in parentheses).

recent estimates by Hauglustaine et al. (2014) and Bellouin et al. (2011), but differs significantly from the Goddard Institute for Space Studies (GISS) (0.023) and the Centre for International Climate and Environmental Research - Oslo (CICERO) (0.002) models. Shindell et al. (2013) reported that convective transport of $\mathrm{NH}_{3}$ to the free troposphere, where $\mathrm{NH}_{4} \mathrm{NO}_{3}$ is stable and sensitive to $\mathrm{NH}_{3}$ (Fig. 7), is responsible for the elevated nitrate in the GISS model. Revisions of the treatment of $\mathrm{NH}_{3}$ convective removal in GISS reduce the simulated present-day $\mathrm{NO}_{3}^{-}$optical depth to 0.005 (S. Bauer, personal communication, 2015).

Shindell et al. (2013) also showed that CICERO may overestimate $\mathrm{SO}_{4}^{2-}$ optical depth, which would inhibit the production of $\mathrm{NH}_{4} \mathrm{NO}_{3}$ by decreasing the amount of free ammonia $\left(\left[\mathrm{NH}_{x}\right]-2\left[\mathrm{SO}_{4}^{2-}\right]\right)$.

Figure 10 shows the annual AM3N nitrate optical depth and its sensitivity to the treatment of $\mathrm{NH}_{3}$ emissions and $\mathrm{NO}_{3}^{-}$chemistry in AM3N. The sensitivity of $\mathrm{NO}_{3}^{-}$optical depth to $\mathrm{NH}_{3}$ seasonality is small and follows the patterns of $\mathrm{NH}_{4} \mathrm{NO}_{3}$ limitations by $\mathrm{NH}_{3}$, with largest sensitivity over the eastern USA and in the outflow of continents The global sensitivity to $\mathrm{NH}_{3}$ seasonality is a lower bound, since the sea- sonality of anthropogenic $\mathrm{NH}_{3}$ emissions is not represented in important source regions (e.g., India, South America) in HTAPv2. We find greater sensitivity to the diurnal cycle of $\mathrm{NH}_{3}$ emissions, which is attributed to increased transport of $\mathrm{NH}_{3}$ into the free troposphere, where $\mathrm{NH}_{4} \mathrm{NO}_{3}$ is more sensitive to $\mathrm{NH}_{3}$ (Fig. 7) and more stable because of colder temperature. Decreasing $\mathrm{HNO}_{3}$ production, either by neglecting its heterogeneous production (AM3N_nhet) or increasing the deposition of $\mathrm{NO}_{3}^{-}$(AM3N_fdep), reduces the annual mean $\mathrm{NO}_{3}^{-}$optical depth by $25 \%$ globally. Regionally, $\mathrm{NO}_{3}^{-}$in polluted regions is more sensitive to the heterogeneous production of $\mathrm{HNO}_{3}$ because of the large aerosol surface area in these regions. Neglecting heterogeneous chemistry on dust results in a large relative increase of $\mathrm{NO}_{3}^{-}$optical depth in dusty regions, but the increase of the global mean $\mathrm{NO}_{3}^{-}$optical depth is small (13\%). This muted response is caused by low $\mathrm{NH}_{3}$ sources near major natural dust sources. A notable exception is anthropogenic dust, whose sources are primarily associated with agriculture (Ginoux et al., 2012a). The proximity of $\mathrm{NH}_{3}$ and anthropogenic dust sources results in $35 \%$ greater sensitivity of $\mathrm{NO}_{3}^{-}$optical depth to anthropogenic dust than to natural dust (per kilogram of dust). 


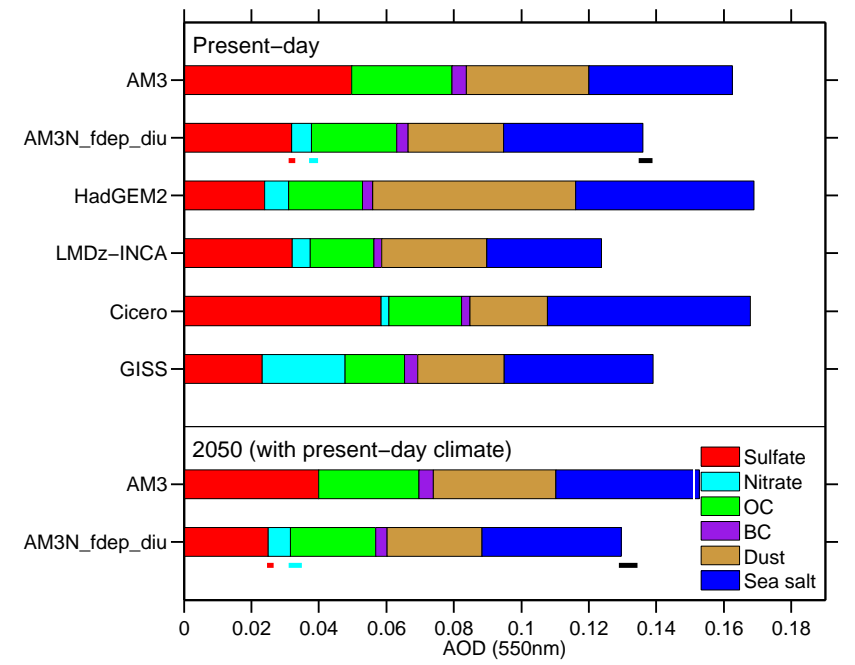

Figure 9. Contribution of different aerosol types to the global mean annual aerosol optical depth at $550 \mathrm{~nm}$ in AM3, AM3N, and other climate models considering $\mathrm{NO}_{3}^{-}$aerosol (all-sky except clearsky for GISS). AM3 and AM3N AOD are representative of 2010 conditions, while other models reflect 2000 conditions. The range of $\mathrm{SO}_{4}^{2-}, \mathrm{NO}_{3}^{-}$, and total AOD across AM3N configurations are shown by red, light blue, and black horizontal bars respectively. Note that changes in the parameterization of $\mathrm{NH}_{3}$ convective removal reduce the simulated $\mathrm{NO}_{3}^{-}$optical depth by GISS to 0.005 (S. Bauer, personal communication, 2015).

\subsection{0 emissions}

Figure 9 shows the contributions of sulfate, nitrate, organic carbon, black carbon, dust, and sea salt to the global mean AOD in AM3 and AM3N_fdep_diu using 2050 emission as described in Sect. 2.2. Sulfate optical depths decrease by $20 \%$ from 2010 to 2050 in both AM3 and AM3N_fdep_diu, similar to Hauglustaine et al. (2014). In all configurations, AM3N produces a small increase of the global mean $\mathrm{NO}_{3}^{-}$ optical depth in response to changes in anthropogenic emissions from 2010 to $2050(<30 \%)$, with $\mathrm{NO}_{3}^{-}$optical depth ranging from 0.0061 (AM3N_fdep) to 0.01 (AM3N_ndust). In $\mathrm{AM} 3 \mathrm{~N}$, the conversion rate from $\mathrm{NH}_{3}$ to $\mathrm{NO}_{3}^{-}$(excluding dust) defined as the molar ratio of the fine $\mathrm{NO}_{3}^{-}$burden to $\mathrm{NH}_{3}$ emissions decreases by $10 \%$ from 0.34 day $^{-1}$ to 0.29 day $^{-1}$. $\mathrm{NH}_{4} \mathrm{NO}_{3}$ lifetime with respect to deposition increases by $25 \%$ under the 2050 emissions, which suggests that the increase in $\mathrm{NO}_{3}^{-}$optical depth in AM3N is driven by reduced sinks rather than increased production. The response of $\mathrm{NO}_{3}^{-}$to changes in anthropogenic emissions is weaker than reported in recent studies. For instance, Hauglustaine et al. (2014) reported a $\mathrm{NO}_{3}^{-}$optical depth of 0.01 for 2050 and an increase of the conversion rate from $\mathrm{NH}_{3}$ to $\mathrm{NO}_{3}^{-}$ from $0.36 \mathrm{day}^{-1}$ to $0.57 \mathrm{day}^{-1}$ from 2000 to 2050 . Using the same anthropogenic emissions, the simulated $\mathrm{NO}_{3}^{-}$optical depth in AM3N in 2050 (the configuration closest to

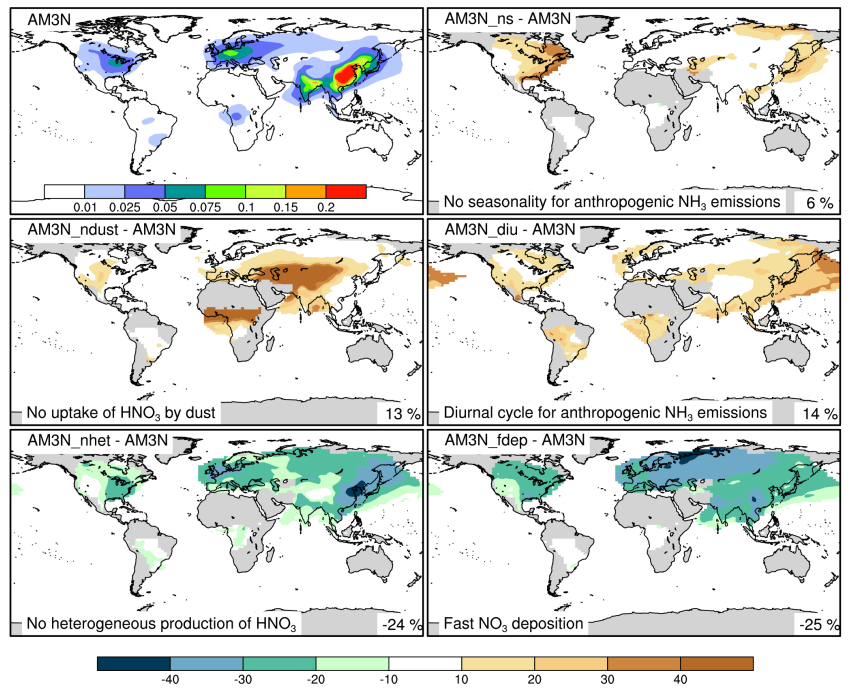

Figure 10. Annual mean $\mathrm{NO}_{3}^{-}$optical depth at $550 \mathrm{~nm}$ in $\mathrm{AM} 3 \mathrm{~N}$ (top left panel) and its relative sensitivity to the treatment of $\mathrm{NH}_{3}$ emissions, $\mathrm{NO}_{3}^{-}$production, and loss in \% for 2008-2010 conditions. The change in $\mathrm{NO}_{3}^{-}$optical depth relative to $\mathrm{AM} 3 \mathrm{~N}$ is indicated in the bottom left for each configuration. The sensitivity is only shown in regions where $\mathrm{NO}_{3}^{-}$optical depth is greater than 0.005 .

that used by Hauglustaine et al., 2014) is 0.077 and the conversion rate from $\mathrm{NH}_{3}$ to $\mathrm{NO}_{3}^{-}$is 0.33 day $^{-1}$.

Figure 11 shows that the simulated $\mathrm{NO}_{3}^{-}$optical depth decreases in all AM3N configurations over Europe and China, increases over India, and exhibits little change over the USA. In all regions $\mathrm{SO}_{2}$ emissions are projected to decrease. This results in greater sensitivity of $\mathrm{NO}_{3}^{-}$optical depth to $\mathrm{HNO}_{3}$, which is reflected in the increase of the sensitivity of $\mathrm{NO}_{3}^{-}$ optical depth to the uptake of $\mathrm{HNO}_{3}$ by dust and lower sensitivity to temporal variations of $\mathrm{NH}_{3}$ emissions (seasonality, diurnal cycle). The sensitivity of $\mathrm{NO}_{3}^{-}$optical depth to the heterogeneous production of $\mathrm{HNO}_{3}$ is reduced despite the increased sensitivity of $\mathrm{NO}_{3}^{-}$to $\mathrm{HNO}_{3}$. This follows the decrease in aerosol surface area associated with the reduction of the $\mathrm{SO}_{4}^{2-}$ burden.

The simulated changes in $\mathrm{NO}_{3}^{-}$optical depth from the present day to 2050 over the USA, China, and Europe are consistent with surface $\mathrm{NH}_{4} \mathrm{NO}_{3}$ limitations. For instance, surface $\mathrm{NH}_{4} \mathrm{NO}_{3}$ is primarily limited by $\mathrm{HNO}_{3}$ in Europe and China and the decrease of $\mathrm{NO}_{3}^{-}$optical depth is driven by the reduction of $\mathrm{NO}$ emissions. In these regions, AM3N simulates similar $\mathrm{NO}_{3}^{-}$optical depth using different anthropogenic emissions of $\mathrm{NH}_{3}$ for 2050, which is also consistent with the reduced sensitivity to $\mathrm{NH}_{3}$ emissions. However, surface $\mathrm{NH}_{4} \mathrm{NO}_{3}$ limitation patterns cannot explain the increase of $\mathrm{NO}_{3}^{-}$optical depth over India.

Figure 12 shows that the $\mathrm{NO}_{3}^{-}$burden is projected to shift equatorward in the Northern Hemisphere in response 


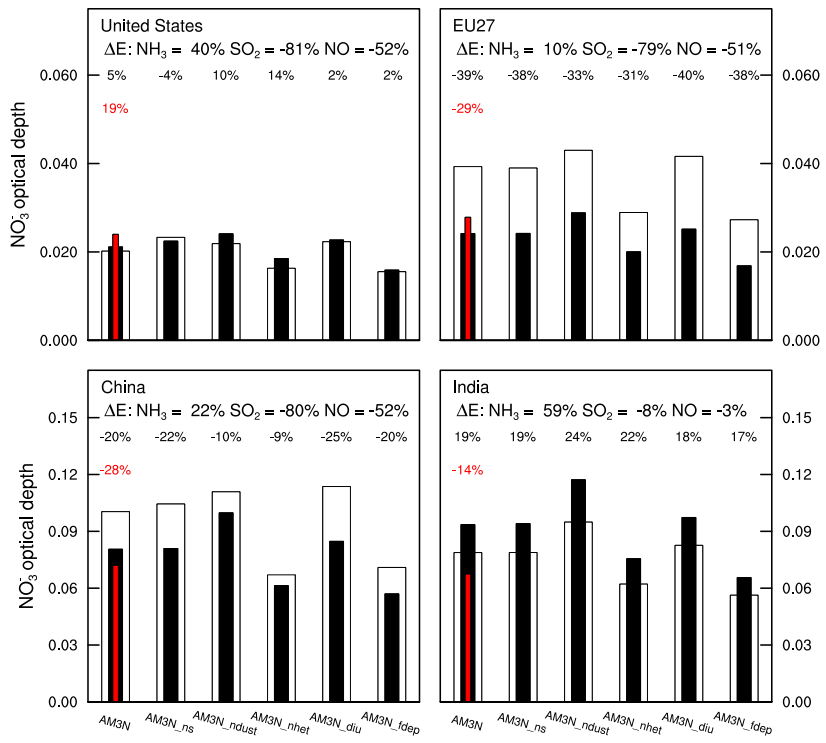

Figure 11. Nitrate optical depth at $550 \mathrm{~nm}$ over the United States, Europe, China, and India for 2008-2010 (white bars) and 2050 (black bars) anthropogenic emissions for different configurations of AM3N. The thin red bar indicates the nitrate optical depth calculated using RCP8.5 $2050 \mathrm{NH}_{3}$ emissions in AM3N. The relative changes between 2008-2010 and 2050 in $\mathrm{NO}_{3}^{-}$optical depth and surface emissions of $\mathrm{NH}_{3}, \mathrm{SO}_{2}$, and $\mathrm{NO}$ are indicated for each region.

to changes in anthropogenic emissions from the present day to $2050 . \mathrm{NH}_{4} \mathrm{NO}_{3}$ increases in the free troposphere but decreases near the surface, a vertical redistribution also noted by Hauglustaine et al. (2014). The decrease of surface $\mathrm{NO}_{3}^{-}$ in the midlatitudes is primarily driven by lower NO emission. Large differences in the seasonality, spatial distribution, and magnitude of anthropogenic $\mathrm{NH}_{3}$ emissions in RCP8.5 (dotted line) and scaled HTAPv2 for 2050 have little impact on the simulated $\mathrm{NO}_{3}^{-}$burden $(<10 \%)$, which reflects the diminishing sensitivity of surface $\mathrm{NH}_{4} \mathrm{NO}_{3}$ to $\mathrm{NH}_{3}$. However, $\mathrm{NO}_{3}^{-}$remains sensitive to $\mathrm{NH}_{3}$ in the free troposphere, where it can persist longer than in the boundary layer thanks to lower temperature. The solid line in Fig. 12 shows the impact of lower convective removal of $\mathrm{NH}_{3}$ (achieved by neglecting the impact of $\mathrm{pH}$ on $\mathrm{NH}_{3}$ solubility) on the $\mathrm{NO}_{3}^{-}$ burden. Over the 2008-2010 period, this results in a $40 \%$ increase of the $\mathrm{NO}_{3}^{-}$burden with a near quadrupling in the tropics, qualitatively matching the results of Hauglustaine et al. (2014) in this region. In 2050, the impact is much more pronounced and the simulated burden is more than twice as large as in 2010, a similar response to that found by Hauglustaine et al. (2014). Note that increasing $\mathrm{NH}_{3}$ emissions from biomass burning and distributing these emissions vertically (Naik et al., 2013a) also increases tropical $\mathrm{NO}_{3}^{-}$(not shown) but to a much lower degree $(<50 \%)$. These results suggest that differences in the transport of $\mathrm{NH}_{3}$ to the free tropo- sphere across models contribute to the variability in the projected $\mathrm{NO}_{3}^{-}$burden and optical depth. Such differences may arise from differences in the parameterizations of convection (Folkins et al., 2006) as suggested by the much lower tropical $\mathrm{NO}_{3}^{-}$burden in AM3N than in the LMDz-INCA model (Hauglustaine et al., 2014) but also from changes in the tropical circulation in response to climate change (e.g., Ma et al., 2012).

\section{Conclusions}

We have developed a new configuration of AM3 (AM3N) with revised treatment of nitrate and sulfate chemistry and deposition. We showed that AM3N better captures observed AOD than a configuration of AM3 similar to that used for ACCMIP and CMIP5. AM3N overestimates surface $\mathrm{NO}_{3}^{-}$ concentration especially in the USA. This bias may reflect neglect in $\mathrm{AM} 3 \mathrm{~N}$ of the dynamic nature of $\mathrm{N}_{2} \mathrm{O}_{5}$ uptake and near-surface volatilization of $\mathrm{NH}_{4} \mathrm{NO}_{3}$.

We have evaluated the sensitivity of $\mathrm{NO}_{3}^{-}$optical depth to poorly constrained aspects of $\mathrm{NO}_{3}^{-}$chemistry (heterogeneous production of $\mathrm{HNO}_{3}$, uptake of $\mathrm{HNO}_{3}$ by natural and anthropogenic dust, surface removal of $\mathrm{NH}_{4} \mathrm{NO}_{3}$ ) and $\mathrm{NH}_{3}$ emissions (diurnal cycle, seasonality). Globally, the formation of $\mathrm{NH}_{4} \mathrm{NO}_{3}$ is more limited by $\mathrm{HNO}_{3}$ than $\mathrm{NH}_{3}$, such that $\mathrm{NO}_{3}^{-}$optical depth is more sensitive to the representation of the heterogeneous chemistry of $\mathrm{HNO}_{3}$ than to uncertainties in $\mathrm{NH}_{3}$ emissions. Simulated present-day $\mathrm{NO}_{3}^{-}$ optical depth ranges from 0.0054 to 0.0082 , depending on the treatment of reactive nitrogen. Differences in the treatment of reactive nitrogen alone are unlikely to account for the large spread in estimates of present-day $\mathrm{NO}_{3}^{-}$optical depth (0.0023-0.025).

We have examined the response of simulated $\mathrm{NO}_{3}^{-}$optical depth to projected changes in anthropogenic emissions from 2010 to 2050 in RCP8.5. Depending on the configuration of AM3N (Table 2), $\mathrm{NO}_{3}^{-}$optical depth varies from 0.0061 to 0.01 in 2050 . The increase of $\mathrm{NO}_{3}^{-}(<30 \%$ relative to 2008-2010) is partly inhibited by greater limitation of $\mathrm{NH}_{4} \mathrm{NO}_{3}$ production by $\mathrm{HNO}_{3}$ at the surface due to lower $\mathrm{NO}$ emissions, more efficient removal of $\mathrm{HNO}_{3}$ by dust, and a large decrease in the heterogeneous production of $\mathrm{HNO}_{3}$ by $\mathrm{N}_{2} \mathrm{O}_{5}$ (associated with lower aerosol surface area). In the Northern Hemisphere, the $\mathrm{NO}_{3}^{-}$burden is projected to shift southward, following the increase of tropical $\mathrm{NH}_{3}$ emissions and the decrease of NO emissions in the midlatitudes. This shift is associated with an increase of the $\mathrm{NO}_{3}^{-}$burden in the free troposphere, where $\mathrm{NH}_{4} \mathrm{NO}_{3}$ formation is limited by $\mathrm{NH}_{3}$. We suggest that the convective transport of $\mathrm{NH}_{3}$ and its response to climate change (not considered here) play an important role in modulating the response of $\mathrm{NO}_{3}^{-}$optical depth to changes in anthropogenic emissions. The complexity of the response of $\mathrm{NO}_{3}^{-}$to changes in surface processes, chemistry, and convection indicates that the global trends of $\mathrm{NH}_{3}$ 


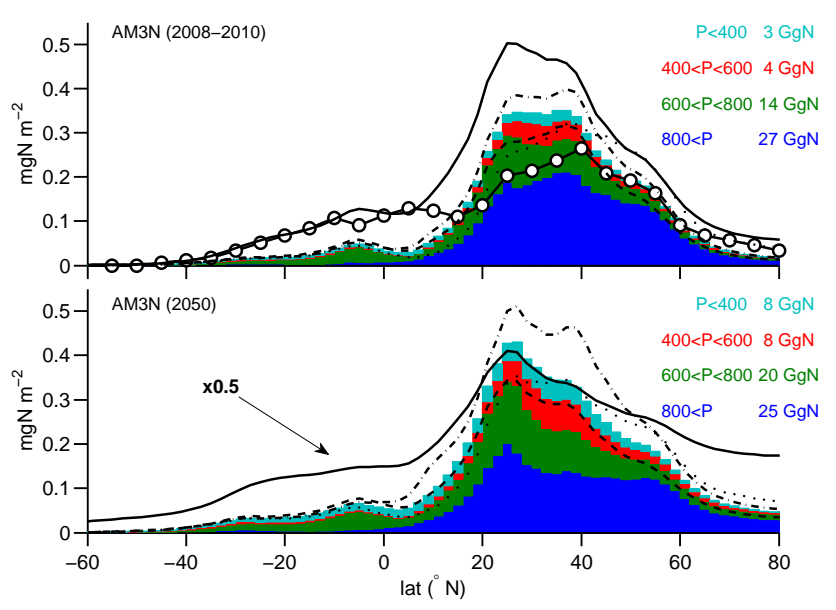

Figure 12. Annual zonal mean distribution of $\mathrm{NO}_{3}^{-}$in $\mathrm{AM} 3 \mathrm{~N}$ with 2008-2010 anthropogenic emissions (top) and 2050 anthropogenic emissions (from RCP8.5 except for $\mathrm{NH}_{3}$; see text). The blue, green, red, and cyan regions denote the $\mathrm{NO}_{3}^{-}$burden located above $800 \mathrm{hPa}$, between 600 and $800 \mathrm{hPa}$, between 400 and $600 \mathrm{hPa}$, and below $400 \mathrm{hPa}$, with the partial burden in each pressure range indicated inset. The annual mean zonal burdens of $\mathrm{NO}_{3}^{-}$simulated using AM3N_fdep_diu (dashed line), using AM3N with anthropogenic emissions from $\mathrm{RCP} 8.5$ for $\mathrm{NH}_{3}$ (dotted line), using AM3N_ndust (dashed dotted line), and using AM3N with reduced convective removal of $\mathrm{NH}_{3}$ (solid line) are also shown. The white circles in the top panel indicate the 2000 annual zonal mean $\mathrm{NO}_{3}^{-}$ burden simulated by Hauglustaine et al. (2014).

emissions may not be a suitable proxy to estimate the future forcing from $\mathrm{NO}_{3}^{-}$aerosols (Heald and Spracklen, 2015).

We conclude that in addition to improvements to $\mathrm{NH}_{3}$ emission inventories (e.g., bidirectional exchange of $\mathrm{NH}_{3}$, Zhu et al., 2015), observational constraints on the processes controlling the vertical redistribution of $\mathrm{NH}_{3}$ and the response of $\mathrm{NO}_{3}^{-}$to $\mathrm{NH}_{3}$ in the free troposphere (e.g., magnitude of $\mathrm{NH}_{3}$ emissions in the tropics (Aneja et al., 2012; Whitburn et al., 2015), biomass burning injection height (Val Martin et al., 2010), transport and removal of $\mathrm{NH}_{3}$ in convective updrafts, heterogeneous chemistry on dust) and sensitivity studies to characterize their response to climate change are needed to improve estimates of present and future $\mathrm{NO}_{3}^{-}$optical depth.

\section{The Supplement related to this article is available online} at doi:10.5194/acp-16-1459-2016-supplement.

Acknowledgements. We are grateful to J. Ogren and B. Andrews for guidance with observations from the NOAA AAO program. We thank D. Ward for helpful discussions. This study was supported by NOAA Climate Program Office's Atmospheric Chemistry, Carbon Cycle, and Climate program and by NASA under grant
NNH14ZDA001N-ACMAP to P. Ginoux and F. Paulot.

Edited by: B. Ervens

\section{References}

Adams, P. J., Seinfeld, J. H., Koch, D., Mickley, L., and Jacob, D.: General circulation model assessment of direct radiative forcing by the sulfate-nitrate-ammonium-water inorganic aerosol system, J. Geophys. Res.-Atmos., 106, 1097-1111, doi:10.1029/2000JD900512, 2001.

Aneja, V. P., Schlesinger, W. H., Erisman, J. W., Behera, S. N., Sharma, M., and Battye, W.: Reactive nitrogen emissions from crop and livestock farming in India, Atmos. Environ., 47, 92103, 2012.

Ansari, A. S. and Pandis, S. N.: Response of Inorganic PM to Precursor Concentrations, Environ. Sci. Technol., 32, 2706-2714, 1998.

Barbaro, E., Krol, M. C., and Vilà-Guerau de Arellano, J.: Numerical simulation of the interaction between ammonium nitrate aerosol and convective boundary-layer dynamics, Atmos. Environ., 105, 202-211, doi:10.1016/j.atmosenv.2015.01.048, 2015.

Bauer, S. E., Koch, D., Unger, N., Metzger, S. M., Shindell, D. T., and Streets, D. G.: Nitrate aerosols today and in 2030: a global simulation including aerosols and tropospheric ozone, Atmos. Chem. Phys., 7, 5043-5059, doi:10.5194/acp-7-5043-2007, 2007.

Bellouin, N., Rae, J., Jones, A., Johnson, C., Haywood, J., and Boucher, O.: Aerosol forcing in the Climate Model Intercomparison Project (CMIP5) simulations by HadGEM2-ES and the role of ammonium nitrate, J. Geophys. Res.-Atmos., 116, D20206, doi:10.1029/2011JD016074, 2011.

Bergin, M. H., Ogren, J. A., Schwartz, S. E., and McInnes, L. M.: Evaporation of Ammonium Nitrate Aerosol in a Heated Nephelometer: Implications for Field Measurements, Environ. Sci. Technol., 31, 2878-2883, doi:10.1021/es970089h, 1997.

Bertram, T. H. and Thornton, J. A.: Toward a general parameterization of $\mathrm{N}_{2} \mathrm{O}_{5}$ reactivity on aqueous particles: the competing effects of particle liquid water, nitrate and chloride, Atmos. Chem. Phys., 9, 8351-8363, doi:10.5194/acp-9-8351-2009, 2009.

Bouwman, A. F., Lee, D. S., Asman, W. A. H., Dentener, F. J., Van Der Hoek, K. W., and Olivier, J. G. J.: A global high-resolution emission inventory for ammonia, Global Biogeochem. Cy., 11, 561-587, 1997.

Brown, S. S. and Stutz, J.: Nighttime radical observations and chemistry, Chem. Soc. Rev., 41, 6405-6447, doi:10.1039/C2CS35181A, 2012.

Brown, S. S., Dubé, W. P., Fuchs, H., Ryerson, T. B., Wollny, A. G., Brock, C. A., Bahreini, R., Middlebrook, A. M., Neuman, J. A., Atlas, E., Roberts, J. M., Osthoff, H. D., Trainer, M., Fehsenfeld, F. C., and Ravishankara, A. R.: Reactive uptake coefficients for $\mathrm{N}_{2} \mathrm{O}_{5}$ determined from aircraft measurements during the Second Texas Air Quality Study: Comparison to current model parameterizations, J. Geophys. Res.-Atmos., 114, D00F10, doi:10.1029/2008JD011679, 2009.

Chang, W. L., Bhave, P. V., Brown, S. S., Riemer, N., Stutz, J., and Dabdub, D.: Heterogeneous Atmospheric Chemistry, Ambient Measurements, and Model Calculations of 
N2O5: A Review, Aerosol Sci. Technol., 45, 665-695, doi:10.1080/02786826.2010.551672, 2011.

Claquin, T., Schulz, M., and Balkanski, Y. J.: Modeling the mineralogy of atmospheric dust sources, J. Geophys. Res.- Atmos., 104, 22243-22256, doi:10.1029/1999JD900416, 1999.

Delene, D. J. and Ogren, J. A.: Variability of Aerosol Optical Properties at Four North American Surface Monitoring Sites, J. Atmos. Sci., 59, 1135-1150, doi:10.1175/15200469(2002)059<1135:VOAOPA>2.0.CO;2, 2002.

Dentener, F. J. and Crutzen, P. J.: Reaction of $\mathrm{N}_{2} \mathrm{O}_{5}$ on Tropospheric Aerosols: Impact on the Global Distributions of $\mathrm{NO}_{x}$, $\mathrm{O}_{3}$, and $\mathrm{OH}, \mathrm{J}$. Geophys. Res., 98, 7149-7163, 1993.

Donner, L. J.: A Cumulus Parameterization Including Mass Fluxes, Vertical Momentum Dynamics, and Mesoscale Effects, J. Atmos. Sci., 50, 889-906, doi:10.1175/15200469(1993)050<0889:ACPIMF>2.0.CO;2, 1993.

Donner, L. J., Wyman, B. L., Hemler, R. S., Horowitz, L. W., Ming, Y., Zhao, M., Golaz, J.-C., Ginoux, P., Lin, S.-J., Schwarzkopf, M. D., Austin, J., Alaka, G., Cooke, W. F., Delworth, T. L., Freidenreich, S. M., Gordon, C. T., Griffies, S. M., Held, I. M., Hurlin, W. J., Klein, S. A., Knutson, T. R., Langenhorst, A. R., Lee, H.-C., Lin, Y., Magi, B. I., Malyshev, S. L., Milly, P. C. D., Naik, V., Nath, M. J., Pincus, R., Ploshay, J. J., Ramaswamy, V., Seman, C. J., Shevliakova, E., Sirutis, J. J., Stern, W. F., Stouffer, R. J., Wilson, R. J., Winton, M., Wittenberg, A. T., and Zeng, F.: The Dynamical Core, Physical Parameterizations, and Basic Simulation Characteristics of the Atmospheric Component AM3 of the GFDL Global Coupled Model CM3, J. Clim., 24, 34843519, doi:10.1175/2011JCLI3955.1, 2011.

Esteve, A. R., Ogren, J. A., Sheridan, P. J., Andrews, E., Holben, B. N., and Utrillas, M. P.: Sources of discrepancy between aerosol optical depth obtained from AERONET and in-situ aircraft profiles, Atmos. Chem. Phys., 12, 2987-3003, doi:10.5194/acp-122987-2012, 2012.

Fairlie, T. D., Jacob, D. J., Dibb, J. E., Alexander, B., Avery, M. A., van Donkelaar, A., and Zhang, L.: Impact of mineral dust on nitrate, sulfate, and ozone in transpacific Asian pollution plumes, Atmos. Chem. Phys., 10, 3999-4012, doi:10.5194/acp-10-39992010, 2010.

Fan, S.-M., Schwarz, J. P., Liu, J., Fahey, D. W., Ginoux, P., Horowitz, L. W., Levy, H., Ming, Y., and Spackman, J. R.: Inferring ice formation processes from global-scale black carbon profiles observed in the remote atmosphere and model simulations, J. Geophys. Res.-Atmos., 117, D23205, doi:10.1029/2012JD018126, 2012.

Fang, Y., Fiore, A. M., Horowitz, L. W., Gnanadesikan, A., Held, I., Chen, G., Vecchi, G., and Levy, H.: The impacts of changing transport and precipitation on pollutant distributions in a future climate, J. Geophys. Res.-Atmos., 116, D18303, doi:10.1029/2011JD015642, 2011.

Feng, Y. and Penner, J. E.: Global modeling of nitrate and ammonium: Interaction of aerosols and tropospheric chemistry, J. Geophys. Res.-Atmos., 112, D01304, doi:10.1029/2005JD006404, 2007.

Folkins, I., Bernath, P., Boone, C., Donner, L. J., Eldering, A., Lesins, G., Martin, R. V., Sinnhuber, B., and Walker, K.: Testing convective parameterizations with tropical measurements of $\mathrm{HNO}_{3}, \mathrm{CO}, \mathrm{H}_{2} \mathrm{O}$, and $\mathrm{O}_{3}$ : Implications for the water vapor budget, J. Geophys. Res.-Atmos., 111, D23304, doi:10.1029/2006JD007325, 2006.

Fountoukis, C. and Nenes, A.: ISORROPIA II: a computationally efficient thermodynamic equilibrium model for $\mathrm{K}^{+}-$ $\mathrm{Ca}^{2+}-\mathrm{Mg}^{2+}-\mathrm{NH}_{4}^{+}-\mathrm{Na}^{+}-\mathrm{SO}_{4}^{2-}-\mathrm{NO}_{3}^{-}-\mathrm{Cl}^{-}-\mathrm{H}_{2} \mathrm{O}$ aerosols, Atmos. Chem. Phys., 7, 4639-4659, doi:10.5194/acp-7-4639-2007, 2007.

Fowler, D., Pilegaard, K., Sutton, M., Ambus, P., Raivonen, M., Duyzer, J., Simpson, D., Fagerli, H., Fuzzi, S., Schjoerring, J., Granier, C., Neftel, A., Isaksen, I., Laj, P., Maione, M., Monks, P., Burkhardt, J., Daemmgen, U., Neirynck, J., Personne, E., Wichink-Kruit, R., Butterbach-Bahl, K., Flechard, C., Tuovinen, J., Coyle, M., Gerosa, G., Loubet, B., Altimir, N., Gruenhage, L., Ammann, C., Cieslik, S., Paoletti, E., Mikkelsen, T., RoPoulsen, H., Cellier, P., Cape, J., Horvàth, L., Loreto, F., Niinemets, U., Palmer, P., Rinne, J., Misztal, P., Nemitz, E., Nilsson, D., Pryor, S., Gallagher, M., Vesala, T., Skiba, U., Brïggemann, N., Zechmeister-Boltenstern, S., Williams, J., O’Dowd, C., Facchini, M., de Leeuw, G., Flossman, A., Chaumerliac, N., and Erisman, J.: Atmospheric composition change: EcosystemsAtmosphere interactions, Atmos. Environ., 43, 5193-5267, aCCENT Synthesis, 2009.

Gaston, C. J., Thornton, J. A., and Ng, N. L.: Reactive uptake of $\mathrm{N}_{2} \mathrm{O}_{5}$ to internally mixed inorganic and organic particles: the role of organic carbon oxidation state and inferred organic phase separations, Atmos. Chem. Phys., 14, 5693-5707, doi:10.5194/acp-14-5693-2014, 2014.

Ginoux, P., Chin, M., Tegen, I., Prospero, J. M., Holben, B., Dubovik, O., and Lin, S.-J.: Sources and distributions of dust aerosols simulated with the GOCART model, J. Geophys. Res.Atmos., 106, 20255-20273, doi:10.1029/2000JD000053, 2001.

Ginoux, P., Clarisse, L., Clerbaux, C., Coheur, P.-F., Dubovik, O., Hsu, N. C., and Van Damme, M.: Mixing of dust and NH3 observed globally over anthropogenic dust sources, Atmos. Chem. Phys., 12, 7351-7363, doi:10.5194/acp-12-7351-2012, 2012a.

Ginoux, P., Prospero, J. M., Gill, T. E., Hsu, N. C., and Zhao, M.: Global-scale attribution of anthropogenic and natural dust sources and their emission rates based on MODIS Deep Blue aerosol products, Rev. Geophys., 50, RG3005, doi:10.1029/2012RG000388, 2012b.

Granier, C., Bessagnet, B., Bond, T., D’Angiola, A., Gon, H. D. v. d., Frost, G. J., Heil, A., Kaiser, J. W., Kinne, S., Klimont, Z., Kloster, S., Lamarque, J.-F., Liousse, C., Masui, T., Meleux, F., Mieville, A., Ohara, T., Raut, J.-C., Riahi, K., Schultz, M. G., Smith, S. J., Thompson, A., Aardenne, J. v., Werf, G. R. v. d., and Vuuren, D. P. v.: Evolution of anthropogenic and biomass burning emissions of air pollutants at global and regional scales during the 1980-2010 period, Clim. Chang., 109, 163-190, doi:10.1007/s10584-011-0154-1, 2011.

Griffiths, P. T. and Anthony Cox, R.: Temperature dependence of heterogeneous uptake of $\mathrm{N} 2 \mathrm{O} 5$ by ammonium sulfate aerosol, Atmos. Sci. Lett., 10, 159-163, doi:10.1002/asl.225, 2009.

Grubbs, F. E.: Sample Criteria for Testing Outlying Observations, Ann. Math. Statist., 21, 27-58, doi:10.1214/aoms/1177729885, 1950.

Guenther, A., Karl, T., Harley, P., Wiedinmyer, C., Palmer, P. I., and Geron, C.: Estimates of global terrestrial isoprene emissions using MEGAN (Model of Emissions of Gases and Aerosols from 
Nature), Atmos. Chem. Phys., 6, 3181-3210, doi:10.5194/acp-63181-2006, 2006.

Hand, J., Gebhart, K., Schichtel, B., and Malm, W.: Increasing trends in wintertime particulate sulfate and nitrate ion concentrations in the Great Plains of the United States (2000-2010), Atmos. Environ., 55, 107-110, doi:10.1016/j.atmosenv.2012.03.050, 2012.

Hauglustaine, D. A., Balkanski, Y., and Schulz, M.: A global model simulation of present and future nitrate aerosols and their direct radiative forcing of climate, Atmos. Chem. Phys., 14, 1103111063, doi:10.5194/acp-14-11031-2014, 2014.

Haywood, J. M. and Ramaswamy, V.: Global sensitivity studies of the direct radiative forcing due to anthropogenic sulfate and black carbon aerosols, J. Geophys. Res.-Atmos., 103, 60436058, doi:10.1029/97JD03426, 1998.

Heald, C. L. and Spracklen, D. V.: Land Use Change Impacts on Air Quality and Climate, Chem. Rev., 115, 4476-4496, doi:10.1021/cr500446g, 2015.

Heald, C. L., Collett Jr., J. L., Lee, T., Benedict, K. B., Schwandner, F. M., Li, Y., Clarisse, L., Hurtmans, D. R., Van Damme, M., Clerbaux, C., Coheur, P.-F., Philip, S., Martin, R. V., and Pye, H. O. T.: Atmospheric ammonia and particulate inorganic nitrogen over the United States, Atmos. Chem. Phys., 12, 10295-10312, doi:10.5194/acp-12-10295-2012, 2012.

Henning, S., Bojinski, S., Diehl, K., Ghan, S., Nyeki, S., Weingartner, E., Wurzler, S., and Baltensperger, U.: Aerosol partitioning in natural mixed-phase clouds, Geophys. Res. Lett., 31, L06101, doi:10.1029/2003GL019025, 2004.

Henze, D. K., Shindell, D. T., Akhtar, F., Spurr, R. J. D., Pinder, R. W., Loughlin, D., Kopacz, M., Singh, K., and Shim, C.: Spatially Refined Aerosol Direct Radiative Forcing Efficiencies, Environ. Sci. Technol., 46, 9511-9518, doi:10.1021/es301993s, 2012.

Horowitz, L. W., Walters, S., Mauzerall, D. L., Emmons, L. K., Rasch, P. J., Granier, C., Tie, X., Lamarque, J.-F., Schultz, M. G., Tyndall, G. S., Orlando, J. J., and Brasseur, G. P.: A global simulation of tropospheric ozone and related tracers: Description and evaluation of MOZART, version 2, J. Geophys. Res.-Atmos., 108, doi:10.1029/2002JD002853, 2003.

Huebert, B. J., Luke, W. T., Delany, A. C., and Brost, R. A.: Measurements of concentrations and dry surface fluxes of atmospheric nitrates in the presence of ammonia, J. Geophys. Res.Atmos., 93, 7127-7136, doi:10.1029/JD093iD06p07127, 1988.

Huneeus, N., Schulz, M., Balkanski, Y., Griesfeller, J., Prospero, J., Kinne, S., Bauer, S., Boucher, O., Chin, M., Dentener, F., Diehl, T., Easter, R., Fillmore, D., Ghan, S., Ginoux, P., Grini, A., Horowitz, L., Koch, D., Krol, M. C., Landing, W., Liu, X., Mahowald, N., Miller, R., Morcrette, J.-J., Myhre, G., Penner, J., Perlwitz, J., Stier, P., Takemura, T., and Zender, C. S.: Global dust model intercomparison in AeroCom phase I, Atmos. Chem. Phys., 11, 7781-7816, doi:10.5194/acp-11-7781-2011, 2011.

Jacobson, M. Z.: Studying the effects of calcium and magnesium on size-distributed nitrate and ammonium with EQUISOLV II, Atmos. Environ., 33, 3635-3649, doi:10.1016/S13522310(99)00105-3, 1999.

Janssens-Maenhout, G., Crippa, M., Guizzardi, D., Dentener, F., Muntean, M., Pouliot, G., Keating, T., Zhang, Q., Kurokawa, J., Wankmüller, R., Denier van der Gon, H., Kuenen, J. J. P., Klimont, Z., Frost, G., Darras, S., Koffi, B., and Li, M.:
HTAP_v2.2: a mosaic of regional and global emission grid maps for 2008 and 2010 to study hemispheric transport of air pollution, Atmos. Chem. Phys., 15, 11411-11432, doi:10.5194/acp15-11411-2015, 2015.

Jordan, C. E., Dibb, J. E., Anderson, B. E., and Fuelberg, H. E.: Uptake of nitrate and sulfate on dust aerosols during TRACE-P, J. Geophys. Res.-Atmos., 108, 8817, doi:10.1029/2002JD003101, 2003.

Kahn, R., Nelson, D., Garay, M., Levy, R., Bull, M., Diner, D., Martonchik, J., Paradise, S., Hansen, E., and Remer, L.: MISR Aerosol Product Attributes and Statistical Comparisons With MODIS, IEEE Trans. Geosci. Remote Sens., 47, 4095-4114, doi:10.1109/TGRS.2009.2023115, 2009.

Kalnay, E., Kanamitsu, M., Kistler, R., Collins, W., Deaven, D., Gandin, L., Iredell, M., Saha, S., White, G., Woollen, J., Zhu, Y., Leetmaa, A., Reynolds, R., Chelliah, M., Ebisuzaki, W., Higgins, W., Janowiak, J., Mo, K. C., Ropelewski, C., Wang, J., Jenne, R., and Joseph, D.: The NCEP/NCAR 40-Year Reanalysis Project, B. Am. Meteorol. Soc., 77, 437-471, doi:10.1175/15200477(1996)077<0437:TNYRP>2.0.CO;2, 1996.

Kim, Y. J., Spak, S. N., Carmichael, G. R., Riemer, N., and Stanier, C. O.: Modeled aerosol nitrate formation pathways during wintertime in the Great Lakes region of North America, J. Geophys. Res.-Atmos., 119, 2014JD022320, doi:10.1002/2014JD022320, 2014.

Lamarque, J.-F., Bond, T. C., Eyring, V., Granier, C., Heil, A., Klimont, Z., Lee, D., Liousse, C., Mieville, A., Owen, B., Schultz, M. G., Shindell, D., Smith, S. J., Stehfest, E., Van Aardenne, J., Cooper, O. R., Kainuma, M., Mahowald, N., McConnell, J. R., Naik, V., Riahi, K., and van Vuuren, D. P.: Historical (1850-2000) gridded anthropogenic and biomass burning emissions of reactive gases and aerosols: methodology and application, Atmos. Chem. Phys., 10, 7017-7039, doi:10.5194/acp10-7017-2010, 2010.

Lamarque, J.-F., Dentener, F., McConnell, J., Ro, C.-U., Shaw, M., Vet, R., Bergmann, D., Cameron-Smith, P., Dalsoren, S., Doherty, R., Faluvegi, G., Ghan, S. J., Josse, B., Lee, Y. H., MacKenzie, I. A., Plummer, D., Shindell, D. T., Skeie, R. B., Stevenson, D. S., Strode, S., Zeng, G., Curran, M., Dahl-Jensen, D., Das, S., Fritzsche, D., and Nolan, M.: Multi-model mean nitrogen and sulfur deposition from the Atmospheric Chemistry and Climate Model Intercomparison Project (ACCMIP): evaluation of historical and projected future changes, Atmos. Chem. Phys., 13, 7997-8018, doi:10.5194/acp-13-7997-2013, 2013.

Lamsal, L. N., Martin, R. V., van Donkelaar, A., Celarier, E. A., Bucsela, E. J., Boersma, K. F., Dirksen, R., Luo, C., and Wang, Y.: Indirect validation of tropospheric nitrogen dioxide retrieved from the OMI satellite instrument: Insight into the seasonal variation of nitrogen oxides at northern midlatitudes, J. Geophys. Res.-Atmos., 115, D05302, doi:10.1029/2009JD013351, 2010.

Lee, C., Martin, R. V., van Donkelaar, A., Lee, H., Dickerson, R. R., Hains, J. C., Krotkov, N., Richter, A., Vinnikov, K., and Schwab, J. J.: SO2 emissions and lifetimes: Estimates from inverse modeling using in situ and global, space-based (SCIAMACHY and OMI) observations, J. Geophys. Res.-Atmos., 116, D06304, doi:10.1029/2010JD014758, 2011.

Lee, Y. H. and Adams, P. J.: Evaluation of aerosol distributions in the GISS-TOMAS global aerosol microphysics model with re- 
mote sensing observations, Atmos. Chem. Phys., 10, 2129-2144, doi:10.5194/acp-10-2129-2010, 2010.

Li, F., Ginoux, P., and Ramaswamy, V.: Distribution, transport, and deposition of mineral dust in the Southern Ocean and Antarctica: Contribution of major sources, J. Geophys. Res.-Atmos., 113, D10207, doi:10.1029/2007JD009190, 2008.

Liao, H., Chen, W., and Seinfeld, J. H.: Role of climate change in global predictions of future tropospheric ozone and aerosols, J. Geophys. Res. Atmos., 111, 12304, doi:10.1029/2005JD006852, 2006.

Lin, M., Fiore, A. M., Horowitz, L. W., Cooper, O. R., Naik, V., Holloway, J., Johnson, B. J., Middlebrook, A. M., Oltmans, S. J., Pollack, I. B., Ryerson, T. B., Warner, J. X., Wiedinmyer, C., Wilson, J., and Wyman, B.: Transport of Asian ozone pollution into surface air over the western United States in spring, J. Geophys. Res.-Atmos., 117, D00V07, doi:10.1029/2011JD016961, 2012.

Liu, J., Fan, S., Horowitz, L. W., and Levy, H.: Evaluation of factors controlling long-range transport of black carbon to the Arctic, J. Geophys. Res. Atmos., 116, D04307, doi:10.1029/2010JD015145, 2011.

Ma, J., Xie, S.-P., and Kosaka, Y.: Mechanisms for Tropical Tropospheric Circulation Change in Response to Global Warming*, J. Climate, 25, 2979-2994, doi:10.1175/JCLI-D-11-00048.1, 2012.

Malm, W. C., Schichtel, B. A., Pitchford, M. L., Ashbaugh, L. L., and Eldred, R. A.: Spatial and monthly trends in speciated fine particle concentration in the United States, J. Geophys. Res.Atmos., 109, D03306, doi:10.1029/2003JD003739, 2004.

Mao, J., Fan, S., Jacob, D. J., and Travis, K. R.: Radical loss in the atmosphere from $\mathrm{Cu}-\mathrm{Fe}$ redox coupling in aerosols, Atmos. Chem. Phys., 13, 509-519, doi:10.5194/acp-13-509-2013, 2013a.

Mao, J., Horowitz, L. W., Naik, V., Fan, S., Liu, J., and Fiore, A. M.: Sensitivity of tropospheric oxidants to biomass burning emissions: implications for radiative forcing, Geophys. Res. Lett., 40, 1241-1246, doi:10.1002/grl.50210, 2013b.

Mao, J., Paulot, F., Jacob, D. J., Cohen, R. C., Crounse, J. D., Wennberg, P. O., Keller, C. A., Hudman, R. C., Barkley, M. P., and Horowitz, L. W.: Ozone and organic nitrates over the eastern United States: Sensitivity to isoprene chemistry, J. Geophys. Res.-Atmos., 118, 11256-11268, doi:10.1002/jgrd.50817, 2013c.

Martin, R. V., Sauvage, B., Folkins, I., Sioris, C. E., Boone, C., Bernath, P., and Ziemke, J.: Space-based constraints on the production of nitric oxide by lightning, J. Geophys. Res.-Atmos., 112, D09309, doi:10.1029/2006JD007831, 2007.

Mauldin III, R. L., Berndt, T., Sipila, M., Paasonen, P., Petaja, T., Kim, S., Kurten, T., Stratmann, F., Kerminen, V. M., and Kulmala, M.: A new atmospherically relevant oxidant of sulphur dioxide, Nature, 488, 193-196, 2012.

Meng, Z. and Seinfeld, J. H.: Time scales to achieve atmospheric gas-aerosol equilibrium for volatile species, Atmos. Environ., 30, 2889-2900, doi:10.1016/1352-2310(95)00493-9, 1996.

Ming, Y., Ramaswamy, V., Donner, L. J., and Phillips, V. T. J.: A New Parameterization of Cloud Droplet Activation Applicable to General Circulation Models, J. Atmos. Sci., 63, 1348-1356, doi:10.1175/JAS3686.1, 2006.

Misselbrook, T., Sutton, M., and Scholefield, D.: A simple processbased model for estimating ammonia emissions from agricultural land after fertilizer applications, Soil Use and Management, 20, 365-372, doi:10.1111/j.1475-2743.2004.tb00385.x, 2004.

Murray, L. T., Jacob, D. J., Logan, J. A., Hudman, R. C., and Koshak, W. J.: Optimized regional and interannual variability of lightning in a global chemical transport model constrained by LIS/OTD satellite data, J. Geophys. Res.-Atmos., 117, D20307, doi:10.1029/2012JD017934, 2012.

Myhre, G., Samset, B. H., Schulz, M., Balkanski, Y., Bauer, S., Berntsen, T. K., Bian, H., Bellouin, N., Chin, M., Diehl, T., Easter, R. C., Feichter, J., Ghan, S. J., Hauglustaine, D., Iversen, T., Kinne, S., Kirkevåg, A., Lamarque, J.-F., Lin, G., Liu, X., Lund, M. T., Luo, G., Ma, X., van Noije, T., Penner, J. E., Rasch, P. J., Ruiz, A., Seland, Ø., Skeie, R. B., Stier, P., Takemura, T., Tsigaridis, K., Wang, P., Wang, Z., Xu, L., Yu, H., Yu, F., Yoon, J.-H., Zhang, K., Zhang, H., and Zhou, C.: Radiative forcing of the direct aerosol effect from AeroCom Phase II simulations, Atmos. Chem. Phys., 13, 1853-1877, doi:10.5194/acp-13-18532013, 2013.

Naik, V., Horowitz, L. W., Fiore, A. M., Ginoux, P., Mao, J., Aghedo, A. M., and Levy, H.: Impact of preindustrial to presentday changes in short-lived pollutant emissions on atmospheric composition and climate forcing, J. Geophys. Res.-Atmos., 118, 8086-8110, doi:10.1002/jgrd.50608, 2013a.

Naik, V., Voulgarakis, A., Fiore, A. M., Horowitz, L. W., Lamarque, J.-F., Lin, M., Prather, M. J., Young, P. J., Bergmann, D., Cameron-Smith, P. J., Cionni, I., Collins, W. J., Dalsøren, S. B., Doherty, R., Eyring, V., Faluvegi, G., Folberth, G. A., Josse, B., Lee, Y. H., MacKenzie, I. A., Nagashima, T., van Noije, T. P. C., Plummer, D. A., Righi, M., Rumbold, S. T., Skeie, R., Shindell, D. T., Stevenson, D. S., Strode, S., Sudo, K., Szopa, S., and Zeng, G.: Preindustrial to present-day changes in tropospheric hydroxyl radical and methane lifetime from the Atmospheric Chemistry and Climate Model Intercomparison Project (ACCMIP), Atmos. Chem. Phys., 13, 5277-5298, doi:10.5194/acp-13-5277-2013, $2013 b$.

Nemitz, E., Sutton, M. A., Wyers, G. P., Otjes, R. P., Mennen, M. G., van Putten, E. M., and Gallagher, M. W.: Gas-particle interactions above a Dutch heathland: II. Concentrations and surface exchange fluxes of atmospheric particles, Atmos. Chem. Phys., 4, 1007-1024, doi:10.5194/acp-4-1007-2004, 2004.

Neu, J. L. and Prather, M. J.: Toward a more physical representation of precipitation scavenging in global chemistry models: cloud overlap and ice physics and their impact on tropospheric ozone, Atmos. Chem. Phys., 12, 3289-3310, doi:10.5194/acp-12-32892012, 2012.

Nguyen, T. B., Crounse, J. D., Teng, A. P., Clair, J. M. S., Paulot, F., Wolfe, G. M., and Wennberg, P. O.: Rapid deposition of oxidized biogenic compounds to a temperate forest, P. Natl. Acad. Sci. USA, 112, E392-E401, doi:10.1073/pnas.1418702112, 2015.

Park, R. S., Lee, S., Shin, S.-K., and Song, C. H.: Contribution of ammonium nitrate to aerosol optical depth and direct radiative forcing by aerosols over East Asia, Atmos. Chem. Phys., 14, 2185-2201, doi:10.5194/acp-14-2185-2014, 2014.

Pathak, R. K., Wu, W. S., and Wang, T.: Summertime $\mathrm{PM}_{2.5}$ ionic species in four major cities of China: nitrate formation in an ammonia-deficient atmosphere, Atmos. Chem. Phys., 9, 17111722, doi:10.5194/acp-9-1711-2009, 2009.

Paulot, F., Jacob, D. J., and Henze, D. K.: Sources and Processes Contributing to Nitrogen Deposition: An Adjoint Model Anal- 
ysis Applied to Biodiversity Hotspots Worldwide, Environ. Sci. Technol., 47, 3226-3233, doi:10.1021/es3027727, 2013.

Paulot, F., Jacob, D. J., Pinder, R. W., Bash, J. O., Travis, K., and Henze, D. K.: Ammonia emissions in the United States, European Union, and China derived by high-resolution inversion of ammonium wet deposition data: Interpretation with a new agricultural emissions inventory (MASAGE_NH3), J. Geophys. Res.-Atmos., 119, 4343-4364, doi:10.1002/2013JD021130, 2014.

Pinder, R. W., Adams, P. J., Pandis, S. N., and Gilliland, A. B.: Temporally resolved ammonia emission inventories: Current estimates, evaluation tools, and measurement needs, J. Geophys. Res.-Atmos., 111, D16310, doi:10.1029/2005JD006603, 2006.

Pinder, R. W., Dennis, R. L., and Bhave, P. V.: Observable indicators of the sensitivity of PM2.5 nitrate to emission reductions-Part I: Derivation of the adjusted gas ratio and applicability at regulatory-relevant time scales, Atmos. Environ., 42, 12751286, doi:10.1016/j.atmosenv.2007.10.039, 2008.

Pringle, K. J., Tost, H., Message, S., Steil, B., Giannadaki, D., Nenes, A., Fountoukis, C., Stier, P., Vignati, E., and Lelieveld, J.: Description and evaluation of GMXe: a new aerosol submodel for global simulations (v1), Geosci. Model Dev., 3, 391-412, doi:10.5194/gmd-3-391-2010, 2010.

Pye, H. O. T., Liao, H., Wu, S., Mickley, L. J., Jacob, D. J., Henze, D. K., and Seinfeld, J. H.: Effect of changes in climate and emissions on future sulfate-nitrate-ammonium aerosol levels in the United States, J. Geophys. Res.-Atmos., 114, D01205, doi:10.1029/2008JD010701, 2009.

Rasmussen, D., Fiore, A., Naik, V., Horowitz, L., McGinnis, S., and Schultz, M.: Surface ozone-temperature relationships in the eastern US: A monthly climatology for evaluating chemistry-climate models, Atmos. Environ., 47, 142-153, doi:10.1016/j.atmosenv.2011.11.021, 2012.

Rattray, G. and Sievering, H.: Dry deposition of ammonia, nitric acid, ammonium, and nitrate to alpine tundra at Niwot Ridge, Colorado, Atmos. Environ., 35, 1105-1109, doi:10.1016/S13522310(00)00276-4, 2001.

Remer, L. A., Kleidman, R. G., Levy, R. C., Kaufman, Y. J., Tanré, D., Mattoo, S., Martins, J. V., Ichoku, C., Koren, I., Yu, H., and Holben, B. N.: Global aerosol climatology from the MODIS satellite sensors, J. Geophys. Res. Atmos., 113, D14S07, doi:10.1029/2007JD009661, 2008.

Schaap, M., van Loon, M., ten Brink, H. M., Dentener, F. J., and Builtjes, P. J. H.: Secondary inorganic aerosol simulations for Europe with special attention to nitrate, Atmos. Chem. Phys., 4, 857-874, doi:10.5194/acp-4-857-2004, 2004.

Schiferl, L. D., Heald, C. L., Nowak, J. B., Holloway, J. S., Neuman, J. A., Bahreini, R., Pollack, I. B., Ryerson, T. B., Wiedinmyer, C., and Murphy, J. G.: An investigation of ammonia and inorganic particulate matter in California during the CalNex campaign, J. Geophys. Res.-Atmos., 119, 2013JD020765, doi:10.1002/2013JD020765, 2014.

Schulz, M., Textor, C., Kinne, S., Balkanski, Y., Bauer, S., Berntsen, T., Berglen, T., Boucher, O., Dentener, F., Guibert, S., Isaksen, I. S. A., Iversen, T., Koch, D., Kirkevåg, A., Liu, X., Montanaro, V., Myhre, G., Penner, J. E., Pitari, G., Reddy, S., Seland, $\varnothing$. ., Stier, P., and Takemura, T.: Radiative forcing by aerosols as derived from the AeroCom present-day and pre-industrial simu- lations, Atmos. Chem. Phys., 6, 5225-5246, doi:10.5194/acp-65225-2006, 2006.

Sheridan, P. J., Andrews, E., Ogren, J. A., Tackett, J. L., and Winker, D. M.: Vertical profiles of aerosol optical properties over central Illinois and comparison with surface and satellite measurements, Atmos. Chem. Phys., 12, 11695-11721, doi:10.5194/acp12-11695-2012, 2012.

Shindell, D. T., Lamarque, J.-F., Schulz, M., Flanner, M., Jiao, C., Chin, M., Young, P. J., Lee, Y. H., Rotstayn, L., Mahowald, N., Milly, G., Faluvegi, G., Balkanski, Y., Collins, W. J., Conley, A. J., Dalsoren, S., Easter, R., Ghan, S., Horowitz, L., Liu, X., Myhre, G., Nagashima, T., Naik, V., Rumbold, S. T., Skeie, R., Sudo, K., Szopa, S., Takemura, T., Voulgarakis, A., Yoon, J.-H., and Lo, F.: Radiative forcing in the ACCMIP historical and future climate simulations, Atmos. Chem. Phys., 13, 2939-2974, doi:10.5194/acp-13-2939-2013, 2013.

Sofen, E. D., Alexander, B., and Kunasek, S. A.: The impact of anthropogenic emissions on atmospheric sulfate production pathways, oxidants, and ice core $\Delta^{17} \mathrm{O}\left(\mathrm{SO}_{4}^{2-}\right)$, Atmos. Chem. Phys., 11, 3565-3578, doi:10.5194/acp-11-3565-2011, 2011.

Song, C. H. and Carmichael, G. R.: Gas-Particle Partitioning of Nitric Acid Modulated by Alkaline Aerosol, J. Atmos. Chem., 40, 1-22, doi:10.1023/A:1010657929716, 2001.

Stelson, A. W. and Seinfeld, J. H.: Relative humidity and temperature dependence of the ammonium nitrate dissociation constant, Atmos. Environ., 16, 983-992, doi:10.1016/00046981(82)90184-6, 1982.

Strong, J. D. O., Vecchi, G. A., and Ginoux, P.: The Response of the Tropical Atlantic and West African Climate to Saharan Dust in a Fully Coupled GCM, J. Clim., 28, 7071-7092, doi:10.1175/JCLI-D-14-00797.1, 2015.

Tang, I. N. and Munkelwitz, H. R.: Water activities, densities, and refractive indices of aqueous sulfates and sodium nitrate droplets of atmospheric importance, J. Geophys. Res.-Atmos., 99, 1880118808, doi:10.1029/94JD01345, 1994.

Tie, X., Emmons, L., Horowitz, L., Brasseur, G., Ridley, B., Atlas, E., Stround, C., Hess, P., Klonecki, A., Madronich, S., Talbot, R., and Dibb, J.: Effect of sulfate aerosol on tropospheric NOx and ozone budgets: Model simulations and TOPSE evidence, J. Geophys. Res.-Atmos., 108, 8364, doi:10.1029/2001JD001508, 2003.

Tie, X., Madronich, S., Walters, S., Edwards, D. P., Ginoux, P., Mahowald, N., Zhang, R., Lou, C., and Brasseur, G.: Assessment of the global impact of aerosols on tropospheric oxidants, J. Geophys. Res.-Atmos., 110, D03204, doi:10.1029/2004JD005359, 2005.

Val Martin, M., Logan, J. A., Kahn, R. A., Leung, F.-Y., Nelson, D. L., and Diner, D. J.: Smoke injection heights from fires in North America: analysis of 5 years of satellite observations, Atmos. Chem. Phys., 10, 1491-1510, doi:10.5194/acp-10-14912010, 2010.

Van Damme, M., Clarisse, L., Heald, C. L., Hurtmans, D., Ngadi, Y., Clerbaux, C., Dolman, A. J., Erisman, J. W., and Coheur, P. F.: Global distributions, time series and error characterization of atmospheric ammonia $\left(\mathrm{NH}_{3}\right)$ from IASI satellite observations, Atmos. Chem. Phys., 14, 2905-2922, doi:10.5194/acp-14-29052014, 2014a.

Van Damme, M., Wichink Kruit, R. J., Schaap, M., Clarisse, L., Clerbaux, C., Coheur, P.-F., Dammers, E., Dolman, A. J., 
and Erisman, J. W.: Evaluating 4 years of atmospheric ammonia $\left(\mathrm{NH}_{3}\right)$ over Europe using IASI satellite observations and LOTOS-EUROS model results, J. Geophys. Res.-Atmos., 119, 9549-9566, doi:10.1002/2014JD021911, 2014b.

Van Oss, R., Duyzer, J., and Wyers, P.: The influence of gasto-particle conversion on measurements of ammonia exchange over forest, Atmos. Environ., 32, 465-471, doi:10.1016/S13522310(97)00280-X, 1998.

van Vuuren, D., Edmonds, J., Kainuma, M., Riahi, K., Thomson, A., Hibbard, K., Hurtt, G., Kram, T., Krey, V., Lamarque, J.F., Masui, T., Meinshausen, M., Nakicenovic, N., Smith, S., and Rose, S.: The representative concentration pathways: an overview, Clim. Change, 109, 5-31, doi:10.1007/s10584-0110148-z, 2011.

Wagner, N. L., Riedel, T. P., Young, C. J., Bahreini, R., Brock, C. A., Dubé, W. P., Kim, S., Middlebrook, A. M., Öztürk, F., Roberts, J. M., Russo, R., Sive, B., Swarthout, R., Thornton, J. A., VandenBoer, T. C., Zhou, Y., and Brown, S. S.: $\mathrm{N}_{2} \mathrm{O}_{5}$ uptake coefficients and nocturnal $\mathrm{NO}_{2}$ removal rates determined from ambient wintertime measurements, J. Geophys. Res.-Atmos., 118, 9331-9350, doi:10.1002/jgrd.50653, 2013.

Walker, J. M., Philip, S., Martin, R. V., and Seinfeld, J. H.: Simulation of nitrate, sulfate, and ammonium aerosols over the United States, Atmos. Chem. Phys., 12, 11213-11227, doi:10.5194/acp12-11213-2012, 2012.

Wang, Q., Jacob, D. J., Fisher, J. A., Mao, J., Leibensperger, E. M., Carouge, C. C., Le Sager, P., Kondo, Y., Jimenez, J. L., Cubison, M. J., and Doherty, S. J.: Sources of carbonaceous aerosols and deposited black carbon in the Arctic in winter-spring: implications for radiative forcing, Atmos. Chem. Phys., 11, 1245312473, doi:10.5194/acp-11-12453-2011, 2011.

West, J. J., Pilinis, C., Nenes, A., and Pandis, S. N.: Marginal direct climate forcing by atmospheric aerosols, Atmos. Environ., 32, 2531-2542, doi:10.1016/S1352-2310(98)00003-X, 1998.

Whitburn, S., Van Damme, M., Kaiser, J., van der Werf, G., Turquety, S., Hurtmans, D., Clarisse, L., Clerbaux, C., and Coheur, P.-F.: Ammonia emissions in tropical biomass burning regions: Comparison between satellite-derived emissions and bottom-up fire inventories, Atmos. Environ., 121, 42-54, doi:10.1016/j.atmosenv.2015.03.015, 2015.
Wiedinmyer, C., Akagi, S. K., Yokelson, R. J., Emmons, L. K., AlSaadi, J. A., Orlando, J. J., and Soja, A. J.: The Fire INventory from NCAR (FINN): a high resolution global model to estimate the emissions from open burning, Geosci. Model Dev., 4, 625641, doi:10.5194/gmd-4-625-2011, 2011.

Wolff, V., Trebs, I., Foken, T., and Meixner, F. X.: Exchange of reactive nitrogen compounds: concentrations and fluxes of total ammonium and total nitrate above a spruce canopy, Biogeosciences, 7, 1729-1744, doi:10.5194/bg-7-1729-2010, 2010.

Wyers, G. P. and Duyzer, J. H.: Micrometeorological measurement of the dry deposition flux of sulphate and nitrate aerosols to coniferous forest, Atmos. Environ., 31, 333-343, doi:10.1016/S1352-2310(96)00188-4, 1997.

$\mathrm{Xu}$, L. and Penner, J. E.: Global simulations of nitrate and ammonium aerosols and their radiative effects, Atmos. Chem. Phys., 12, 9479-9504, doi:10.5194/acp-12-9479-2012, 2012.

Ying, Q., Wu, L., and Zhang, H.: Local and inter-regional contributions to PM2.5 nitrate and sulfate in China, Atmos. Environ., 94, 582-592, doi:10.1016/j.atmosenv.2014.05.078, 2014.

Zhu, L., Henze, D. K., Cady-Pereira, K. E., Shephard, M. W., Luo, M., Pinder, R. W., Bash, J. O., and Jeong, G.-R.: Constraining U.S. ammonia emissions using TES remote sensing observations and the GEOS-Chem adjoint model, J. Geophys. Res.-Atmos., 118, 3355-3368, doi:10.1002/jgrd.50166, 2013.

Zhu, L., Henze, D., Bash, J., Jeong, G.-R., Cady-Pereira, K., Shephard, M., Luo, M., Paulot, F., and Capps, S.: Global evaluation of ammonia bidirectional exchange and livestock diurnal variation schemes, Atmos. Chem. Phys., 15, 12823-12843, doi:10.5194/acp-15-12823-2015, 2015.

Zhuang, H., Chan, C. K., Fang, M., and Wexler, A. S.: Size distributions of particulate sulfate, nitrate, and ammonium at a coastal site in Hong Kong, Atmos. Environ., 33, 843-853, doi:10.1016/S1352-2310(99)00186-7, 1999. 